\title{
Hydrolytic Proteins of Sugarcane: The Acid Phosphatases
}

\author{
Alex G. Alexander ${ }^{1}$
}

\section{INTRODUCTION}

Although phosphatase activity was known in rice, yeast, and numerous animal tissues almost 60 years ago, its physiological necessity was first demonstrated by Robison and Soames $(30)^{2}$ in 1924 . In that year a theory of bone formation was advanced from the observations that a precipitate of tricalcium phosphate is produced when phosphatase acts upon hexose monophosphate in the presence of calcium. Since that time, a great many phosphatases have been discovered, and they are now known to be essential for the metabolism of carbohydrates, nucleotides, and phospholipids, and for the process of muscular contraction.

The typical hydrolytic reaction catalyzed by phosphatase can be written

$$
\mathrm{R}-\mathrm{O}-\mathrm{PO}_{3} \mathrm{H}_{2}+\mathrm{H}_{2} \mathrm{O} \rightarrow \mathrm{ROH}+\mathrm{H}_{3} \mathrm{PO}_{4}
$$

where $\mathrm{R}-\mathrm{O}-\mathrm{PO}_{3} \mathrm{H}_{2}$ is the substrate or donor, $\mathrm{R}$ is the transferable group of the donor, and $\mathrm{H}_{2} \mathrm{O}$ is the final acceptor of the transferable group. The common use of water poses a difficult problem when classifying the phosphatases, since the end result of their reactions is essentially the same. The usually reliable property of substrate specificity is of little value in these instances. Other properties, such as $\mathrm{pH}$ optima, specificity of activators and inhibitors, and the number of esters of phosphoric acid comprising the substrate molecule have been employed to help classify these systems. Hence, terms such as acid phosphatases, alkaline phosphatases, phosphomonoesterases, phosphodiesterases, and pyrophosphatases are commonly used to distinguish one group from another.

In 1936, Ignatieff and Wasteneys (15) reported phosphatases in various tissues of the bean, potato, radish, and wheat. Axelrod and Jagendorf ( $(3)$ found that phosphatase, as well as catalase and invertase, remained stable in detached, autolyzing tobacco leaves, even though total leaf protein rapidly declined. Other investigators observed the inhibitory effects of molybdenum (Mo) on the acid phosphatases of higher plants $(5,22)$ and of yeast (31). Recognizing the importance of reactions which destroy biochemical compounds such as the hexose phosphates and adenosine triphosphate (ATP), Spencer (33) investigated the Mo-inhibition of the

1 Associate Plant Physiologist, Agricultural Experiment Station, University of Puerto Rico, Río Piedras, P.R.

2 Italic numbers in parentheses refer to Literature Cited, pp. 226-8. 
tomato acid phosphatases, and concluded that phosphatase inhibition is a metabolic function of Mo.

Acid phosphatase was encountered in sugarcane-leaf preparations while the author was conducting a survey of sugar-metabolizing enzymes (1). Every substrate tested was readily attacked. ${ }^{3}$ Fractionation of leaf extracts with ammonium sulfate yielded phosphatase between 28- and 100percent saturation, and it was felt that a number of phosphatases might be involved. Because such enzymes assume great importance by attacking ATP and the phosphorylated precursors of sucrose, considerable effort is being made to understand the types and behavior of these catalysts in sugarcane. This paper summarizes the properties of two broad groups of acid phosphatases extracted from sugarcane-leaf tissue.

\section{EXPERIMENTAL PROCEDURE}

\section{PREPARATION OF ENZYME}

Enzyme preparations were made with distilled-water extracts of lyophilized leaf tissue from 4-month-old sugarcane of the variety $M$. 336. The basal 14 inches of leaves +1 to +4 were inserted in large culture tubes and frozen in a mixture of Dry Ice (solid carbon dioxide) and acetone. The samples were then freeze-dried and ground to pass a 60 -mesh screen. The powdered tissues were sealed in sample jars and stored at $-20^{\circ} \mathrm{C}$.

Phosphatase was removed from water extracts by precipitation with ammonium sulfate. Salt fractionation has been used successfully for yeast pyrophosphatase (14), apyrase of potato $(16,17,28)$, and ATP-ase of yeast (25), with the enzymes usually precipitating below 60 -percent saturation.

It was found that phosphatase was removed from cane-leaf extracts at saturation values as low as 28 and as high as 100 percent. Analysis of protein salted out at 5-percent increments showed predominant phosphatase activity between 40 - and 60-percent saturation. Further fractionation experiments with 2-percent increments failed to reveal precise saturation points when ATP, ADP, glucose-1-phosphate, glucose-6-phosphate, and $\beta$-glycerophosphate were used as test substrates. In each instance, however, maximum enzyme activity was found between 48- and 58-percent saturation, which accounted for approximately 70 percent of the total phosphatase activity in the original extract. The 48- to 58-percent fraction was employed as enzyme source throughout the remainder of the study.

The following procedure was adopted for obtaining a standard leafphosphatase preparation: Thirty grams of leaf powder were extracted for

${ }^{3}$ Substrates found to be hydrolyzed included the hexose phosphates, phosphoglyceric acid, UTP (uridine triphosphate), ATP (adenosine triphosphate), ADP (adenosine diphosphate), and $\beta$-glycerophosphate. 
1 hour with $300 \mathrm{ml}$. of distilled water. All extractions were carried out at $22^{\circ} \mathrm{C}$. and were facilitated with a mechanical shaker operating at slow speed. Tissue debris was removed by expressing the mixture through six layers of absorbent gauze $(20 \times 12 \mathrm{mesh})$. The suspension was clarified by centrifuge for 10 minutes at 3,500 r.p.m. Exactly $250 \mathrm{ml}$. of the supernatant liquid was adjusted to $\mathrm{pH} 7.0$ with $2 \mathrm{~N} \mathrm{NaOH}$, and sufficient solid ammonium sulfate was added to achieve 48-percent saturation. The salt was added slowly with constant stirring over a 15-minute interval. The suspension was clarified by centrifuge and the protein residue discarded. Ammonium sulfate was again added to bring the supernatant liquid to 58-percent saturation. Upon reclarification by centrifuge, the supernatant liquid was discarded and the protein residue was taken up in $5 \mathrm{ml}$. of 50-percent glycerol solution, after the technique of Meyerhof and Ohlmeyer (25), who found that yeast ATP-ase was more stable in glycerol solution than in water.

Stability of the phosphatase preparation was tested at varying temperatures over an 8-day period, using samples made up in 50-percent glycerol and others made up in distilled water. Greatest stability was obtained with glycerol solutions. These retained about 90 percent of their activity for 2 days when stored at $2^{\circ} \mathrm{C}$. However, the preparations lost 56 percent of their activity within 8 days, and consequently all tests during the present study were made with extracts which were no more than 48 hours old, and which were retained continuously under refrigeration.

\section{PHOSPHATASE ASSAYS}

Phosphatase was measured by determining the amount of inorganic phosphorus released from the substrate by enzyme action under controlled conditions. The reaction mixture for the standard test was composed of $0.5 \mathrm{ml}$. of acetate buffer ( $\mathrm{pH} 4.65$ ), $0.5 \mathrm{ml}$. of substrate solution, $0.25 \mathrm{ml}$. of distilled water or additive, and $0.25 \mathrm{ml}$. of enzyme preparation. The test was run for 20 minutes at $30^{\circ} \mathrm{C}$. Two milliliters of 10-percent trichloroacetic acid were used to stop the reaction. After removing the protein precipitate by centrifuge, $1 \mathrm{ml}$. of the supernatant liquid was withdrawn for color development by the phosphomolybdic acid technique described previously (1).

All phosphatase reactions are expressed as specific activity (units per milligrams of protein). The phosphatase activity unit was arbitrarily defined as the amount of enzyme catalyzing the release of $0.01 \mathrm{mg}$. of inorganic phosphorus under the prescribed conditions of the assay. Protein content of the enzyme preparations was determined colorimetrically by the micromethod of Sutherland et al. (36). 


\section{RESULTS AND DISCUSSION}

\section{EFFECTS OF VARIABLE pH UPON SUGARCANE PHOSPHATASE}

Employing ATP, ADP, and $\beta$-glycerophosphate as substrates, phosphatase assays were run over a broad pH range of 3 to 7 (table 1, fig. 1).

TABLE 1.-Effects of variable pH upon the hydrolysis of ATP, ADP, and $\beta$-glycerophosphate by phosphatase preparation from leaves of sugarcane ${ }^{1}$

\begin{tabular}{c|r|r|r|r|r|r|r|r|r|r|r|r}
\hline \multirow{2}{*}{ Substrate } & \multicolumn{10}{|c}{ Specific activity, units/mg. of protein, at pH- } \\
\cline { 2 - 8 } & 3.00 & 3.50 & 4.00 & 4.50 & 4.75 & 5.00 & 5.25 & 5.50 & 5.75 & 6.00 & 6.50 & 7.00 \\
\hline ATP & 33 & 42 & 101 & 130 & 165 & 222 & 125 & 179 & 218 & 269 & 109 & 42 \\
ADP & 25 & 79 & 95 & 94 & 102 & 100 & 94 & 107 & 102 & 100 & 107 & 87 \\
$\begin{array}{c}\beta \text {-glycerophos- } \\
\text { phate }\end{array}$ & 50 & 71 & 122 & 143 & 180 & 183 & 132 & 122 & 107 & 70 & 30 & 38 \\
\hline
\end{tabular}

1 Each reaction mixture was composed of $0.5 \mathrm{ml}$. of buffer, $0.5 \mathrm{ml}$. of substrate (10 $\mu \mathrm{moles} / \mathrm{ml}$. of digest), and $0.25 \mathrm{ml}$. of enzyme preparation. Each reaction proceeded for 20 minutes at $30^{\circ} \mathrm{C}$.

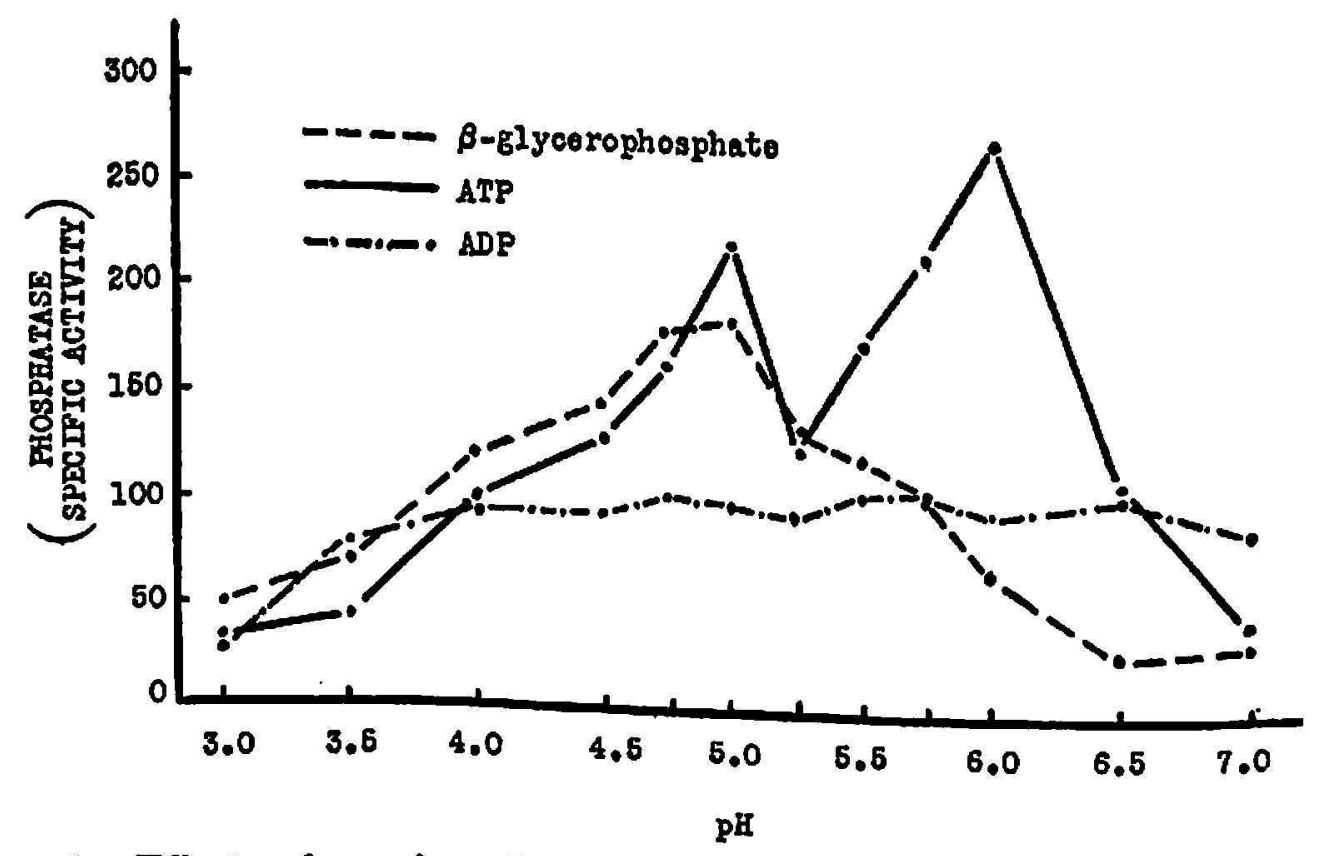

Fra. 1.-Effects of varying $\mathrm{pH}$ upon the ATP, ADP, and $\beta$-glycerophosphatehydrolyzing enzymes from leaves of sugarcane.

The results gave the first clear indication that more than one protein species is involved in the phosphatase reaction. Optimum ATP hydrolysis was taking place at two distinct $\mathrm{pH}$ levels, 5 and 6 (fig. 1 ). $\beta$-glycerophosphate was attacked most readily at $\mathrm{pH} 4.75$ and 5.00 , while the ADP reaction was indifferent to $\mathrm{pH}$ and proceeded moderately from $\mathrm{pH} 3.5$ to 7.0 . 


\section{EFFECTS OF VARLABLE SUBSTRATE CONCENTRATION}

The phosphatase reaction was tested against variable concentrations of ATP, ADP, and $\beta$-glycerophosphate (table 2). Again, the responses were characteristic of at least two different types of enzyme protein. Both the ATP and ADP reactions reached a maximum rate in the area of 1 to 5 $\mu$ moles per milliliter of digest. Subsequent tests showed that both substrates strongly inhibit their own reaction when supplied in quantities greater than $10 \mu$ moles per milliliter. $\beta$-glycerophosphate, on the other hand, induced a far stronger reaction at $10 \mu$ moles than at 5 , and the reaction increased

TABLE 2.-Effects of variable substrate concentration, in terms of specific activity (units/mg. of protein), upon the hydrolysis of $A T P, A D P$, and $\beta$-glycerophosphate by phosphatase preparations from leaves of sugarcane ${ }^{1}$

\begin{tabular}{|c|c|c|c|c|c|c|}
\hline \multicolumn{7}{|c|}{ Substrate concentration al umoles/ml. of digest indicated- } \\
\hline Substrate & 0.1 & 0.3 & 0.6 & 1 & 5 & 10 \\
\hline $\begin{array}{l}\text { ATP } \\
\text { ADP }\end{array}$ & $\begin{array}{l}50 \\
37\end{array}$ & $\begin{array}{r}115 \\
62\end{array}$ & $\begin{array}{r}170 \\
72\end{array}$ & $\begin{array}{r}205 \\
95\end{array}$ & $\begin{array}{r}188 \\
96\end{array}$ & $\begin{array}{r}188 \\
74\end{array}$ \\
\hline
\end{tabular}

Substrate concentration (umoles/ml of digesl)

\begin{tabular}{l|c|c|c|c|c|c|c|c|c}
\hline & 0.5 & 1 & 5 & 10 & 20 & 40 & 60 & 80 & 100 \\
\cline { 2 - 6 } $\begin{array}{c}\beta \text {-Glycero- } \\
\text { phosphate }\end{array}$ & 24 & 28 & 53 & 102 & 110 & 115 & 120 & 132 & 128 \\
\hline
\end{tabular}

${ }^{1}$ Each reaction mixture was composed by $0.5 \mathrm{ml}$. of acetate buffer ( $\mathrm{pH} \mathrm{4.65)}$, $0.5 \mathrm{ml}$. of substrate solution, and $0.25 \mathrm{ml}$. of enzyme preparation. Each reaction proceeded for 20 minutes at $30^{\circ} \mathrm{C}$.

moderately even when the substrate supply was raised to $100 \mu$ moles per milliliter of digest.

\section{EFFECTS OF VARIABLE TEMPERATURE}

Probably no other factor bears quite so heavily as temperature upon the welfare and activity of enzyme protein. In general, the investigator will maintain his enzyme preparations at as low a temperature as his facilities permit, and it takes only a few unfortunate experiences with high temperatures to confirm the wisdom of this practice. It is essential to subject the enzymes to brief periods of relatively high temperatures so that their activity potential can be studied. For convenience, we have run practically all sugarcane cnzyme studies at $30^{\circ} \mathrm{C}$. Many workers prefer $37^{\circ} \mathrm{C}$, and rarely is there mention in the literature of reactions run above $40^{\circ} \mathrm{C}$.

The sugarcane phosphatases were measured at temperatures ranging from 
$20^{\circ} \mathrm{C}$. to $48^{\circ} \mathrm{C}$. The lower temperature is well below the optimum for most of the sugarcane systems we have studied, and the higher temperature will retard most heat-sensitive enzymes. The results are illustrated by figure 2 . The ATP reaction varied but little between $20^{\circ}$ and $30^{\circ} \mathrm{C}$, and, as anticipated, the enzymes involved declined as the temperature approached $48^{\circ} \mathrm{C}$. On the other hand, the hydrolysis of $\beta$-glycerophosphate increased linearly from $20^{\circ}$ to $48^{\circ} \mathrm{C}$. It was the work of a remarkably rugged enzyme (or enzymes), and again appears to be distinct from the catalysts attacking ATP.

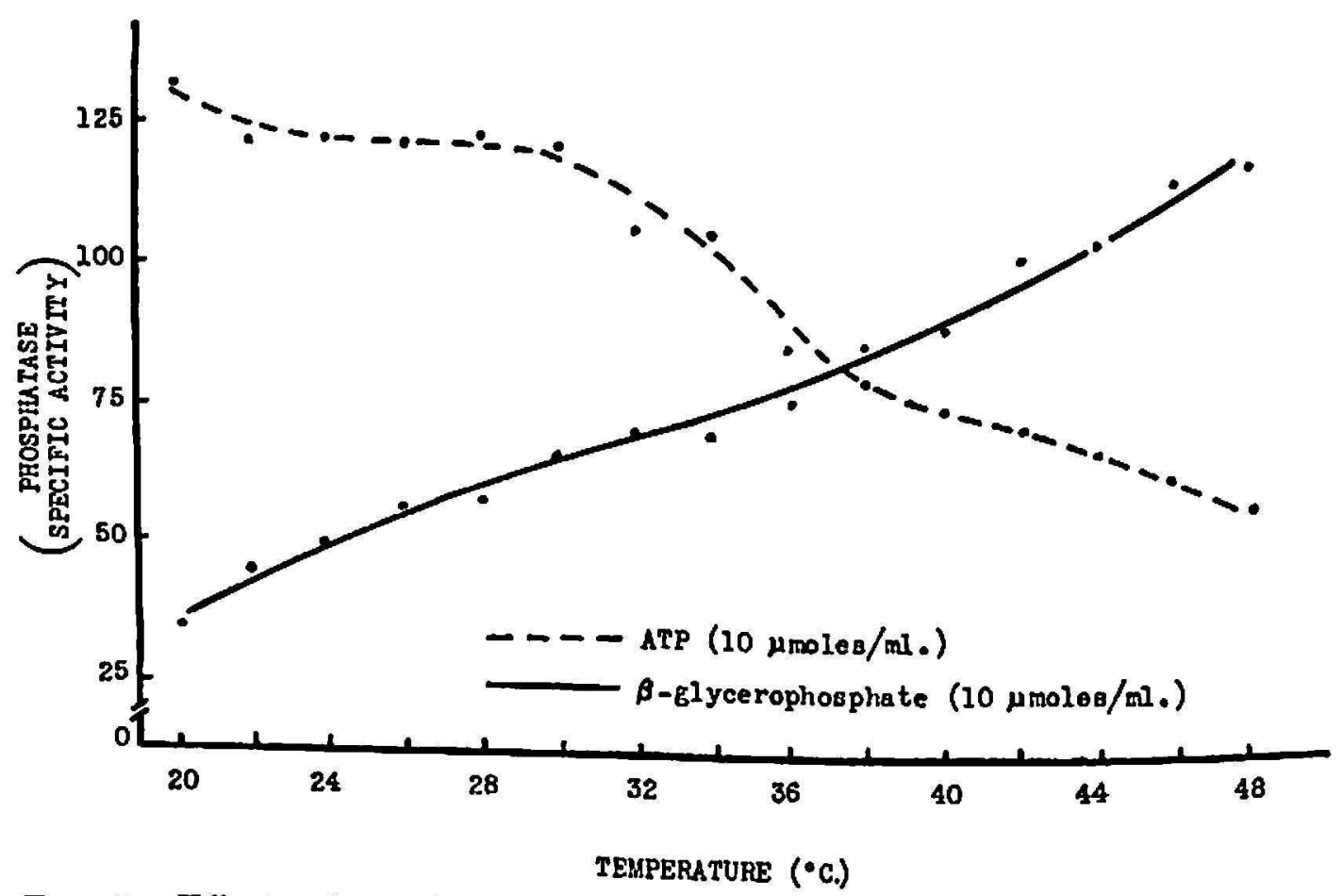

FIG. 2.-Effects of varying temperature upon the ATP and $\beta$-glycerophosphatehydrolyzing enzymes from leaves of sugareane.

The results of $\mathrm{pH}$, substrate, and temperature experiments confirmed the suspicion that more than one type of phosphatase is present in the leaves of sugarcane. Much more work needs to be done before even an approximate number of specific enzymes can be put forward. At the moment, however, we can be certain that at least two groups are present, one which is closely allied with the adenylic acid system, and another which readily attacks monoesters of phosphoric acid. The first group would include ATP-ase and apyrase, while the second would be classified among the "phosphomonoesterases", which hydrolyze such compounds as glucose-6-phosphate and hexose diphosphate.

$\beta$-glycerophosphate is one of the most commonly employed substrates for general phosphatase determinations, and even when a specific phosphatase is being studied the investigator will often test its effects upon 
glycerophosphate out of curiosity. Spencer (39) tested the tomato acid phosphatases against an array of sugar phosphates, ATP, and $\beta$-glycerophosphate. The reaction against $\beta$-glycerophosphate was generally comparable to that of the sugar esters. This agrees closely with our previous work with sugarcane phosphatase, and, as was true of the sugarcane preparations, the reaction against glucose-1-phosphate was found to proceed more slowly than against any other sugar phosphate. Usually, but not always, variable sugarcane treatments induced sugar-phosphatase fluctuations which were reflected in the $\beta$-glycerophosphate reaction. $\beta$-glycerophosphate therefore appears to be the single most representative substrate one can use when studying the phosphomonoesterases of cane. The work discussed through the remainder of this paper centers upon the $\beta$-glycerophosphate reaction.

\section{EFFECTS OF ACTIVATORS AND INHIBITORS}

\section{Activating Effects of Arsenate and Copper}

A series of 13 additives were tested for their effects upon the sugarcane phosphatases at the rate of $10 \mu$ moles per milliliter of digest. Arsenate vastly increased the reaction against $\beta$-glycerophosphate (fig. 3 ) and ATP (fig. 4). Inhibitory effects were recorded for zinc $(\mathrm{Zn})$, manganese $(\mathrm{Mn})$, molybdenum (Mo), cyanide (KCN), bromide ( $\mathrm{Br}$ ), calcium (Ca), and boron (B). With the exception of arsenate, none of the additives appreciably affected the ATP reaction.

According to Sumner (35), arsenic compounds inhibit alkaline phosphatase and "pyrophosphatase I", the enzyme catalyzing the conversion of pyrophosphates to orthophosphates. Neilands and Stumpf (26) list arsenate as an inhibitor of reactions similar to that of phosphotransacetylase, in which arsenate acts as a competitive acceptor against phosphate. Arsenate can be used in place of phosphate in the phosphorylase reactions, with the subsequent formation of glucose-1-arsenate (12). The experiments with sugarcane preparations provide the first evidence we have found that arsenate can act as a phosphatase activator.

In order to analyze in more detail the prospective inhibitors of the $\beta$ glycerophosphate hydrolysis, it was necessary to test these additives at concentrations above and below the $10 \mu$ moles per milliliter originally employed. However, some decision first had to be made regarding the arsenate activation. It is clear from figures 3 and 4 that the control phosphatase reaction proceeded at no more than 25 percent of its potential, as exemplified by the really striking activity when arsenate was added. We therefore assumed that arsenate is a true activator of both types of acid phosphatase encountered in sugarcane, and that the best approach to 


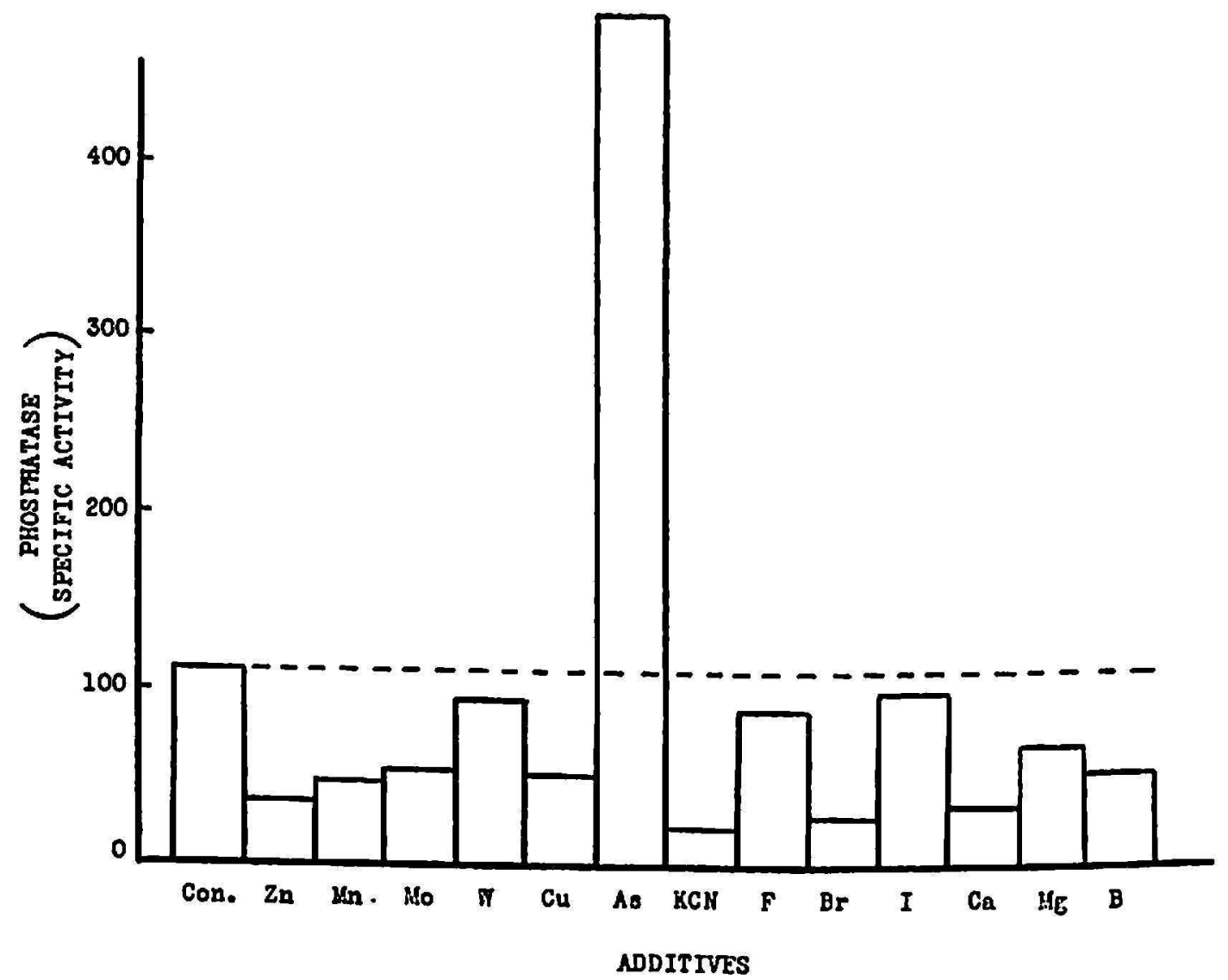

FIG. 3.--Effects of additives upon the hydrolysis of $\beta$-glycerophosphate by phosphatase preparation from leaves of sugarcane.

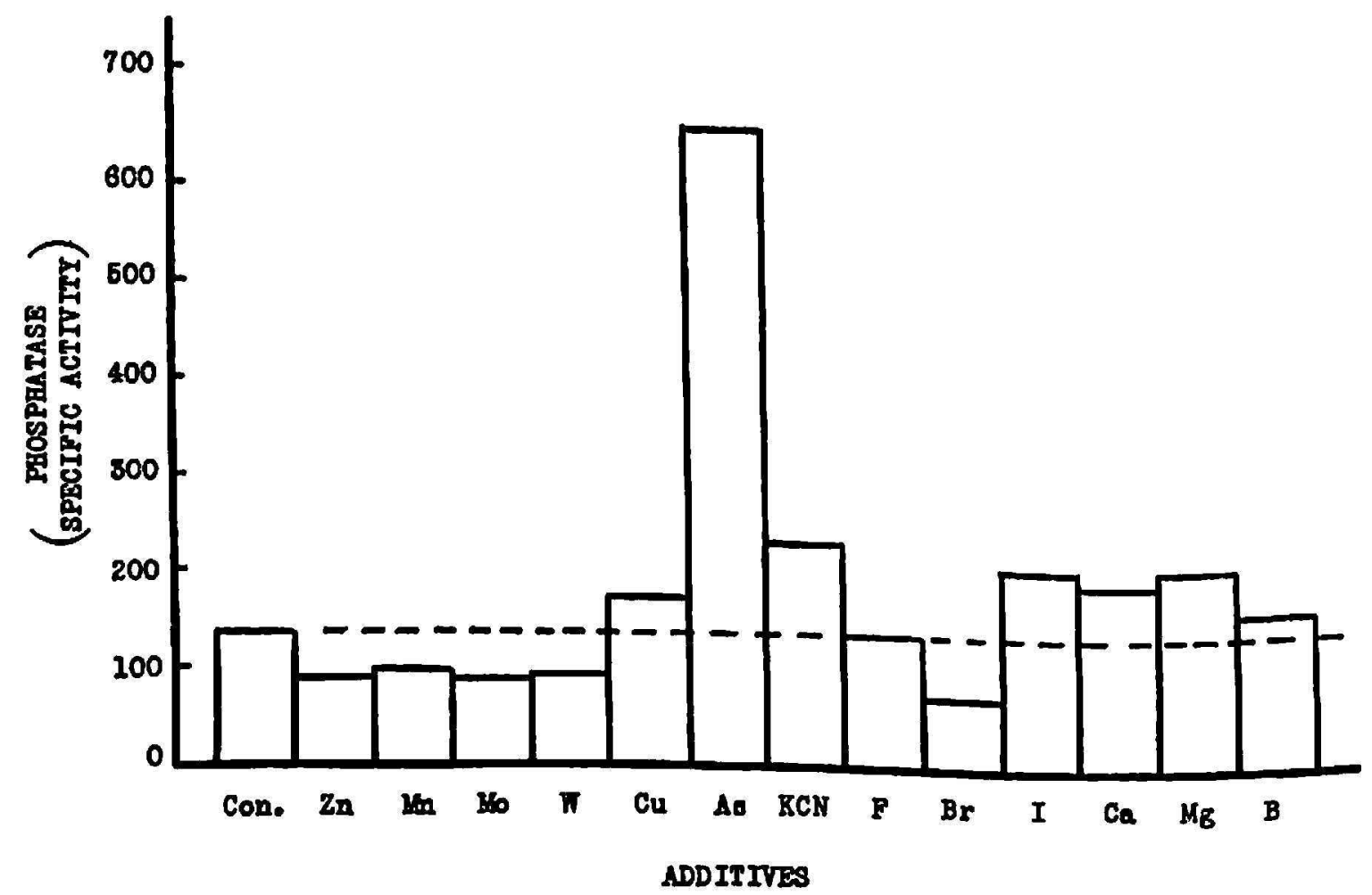

FIG. 4.-Effects of additives upon the hydrolysis of ATP by phosphatase preparation from leaves of sugarcane. 
inhibitor studies would be to analyze the inhibitor effects upon a phosphatase curve derived by gradually increasing levels of arsenate. A series of seven potential inhibitors $(\mathrm{Br}, \mathrm{Zn}, \mathrm{Mn}, \mathrm{Mo}, \mathrm{Ca}, \mathrm{B}$, and $\mathrm{Cu}$ ) was tested in this manner (table 3 ).

TABLE 3.-Effects of variable ions, in terms of specific activity (units/mg. of protein), upon the arsenate-activated hydrolysis of $\beta$-glycerophosphate by phosphatase preparation from leaves of sugarcane ${ }^{1}$

\begin{tabular}{|c|c|c|c|c|c|c|c|c|c|}
\hline \multirow{2}{*}{ Element } & \multirow{2}{*}{ Treatment, $\mu$ moles $/ \mathrm{ml}$. of digest } & \multicolumn{8}{|c|}{ As, at $\mu \mathrm{moles} / \mathrm{ml}$. of digest indicated- } \\
\hline & & 0 & 0.01 & 0.1 & 0.5 & 1 & 3 & 6 & 10 \\
\hline \multirow[t]{3}{*}{$\mathrm{Br}$} & st $+\mathrm{H}_{2} \mathrm{O}$ & 93 & 82 & 73 & 100 & 146 & 290 & 546 & 19 \\
\hline & gest $+5 \mu$ moles $\mathrm{Br}$ & 80 & 89 & 80 & 120 & 130 & 334 & 587 & 78 \\
\hline & Standard digest $+50 \mu$ moles $\mathrm{Br}$ & 124 & 146 & 142 & 210 & 238 & 446 & 736 & 85 \\
\hline \multirow[t]{3}{*}{$\mathbf{Z n}_{\mathbf{n}}$} & Standard digest $+\mathrm{H}_{2} \mathrm{O}$ & 151 & 131 & 116 & 107 & 131 & 227 & 353 & 54 \\
\hline & ard digest $+5 \mu$ moles $\mathrm{Zn}$ & 27 & 27 & 54 & 98 & 136 & 273 & 429 & 602 \\
\hline & Standard digest $+50 \mu$ moles $\mathrm{Zn}$ & 0 & 0 & 49 & 111 & 153 & 286 & 473 & 667 \\
\hline \multirow[t]{3}{*}{$\mathbf{M n}$} & $+\mathrm{H}_{2} \mathrm{O}$ & 100 & 100 & 96 & 89 & 98 & 158 & 273 & 378 \\
\hline & igest $+2 \mu$ moles $\mathrm{Mn}$ & 54 & $\begin{array}{r}200 \\
58\end{array}$ & 71 & 104 & 126 & 196 & 306 & 467 \\
\hline & rd digest $+20 \mu$ moles $\mathrm{Mn}$ & 0 & 0 & 24 & 76 & 109 & 211 & 378 & 49 \\
\hline \multirow[t]{3}{*}{ Mo } & rd digest $+\mathrm{H}_{2} \mathrm{O}$ & 124 & 106 & 96 & 127 & 147 & 220 & 358 & 49 \\
\hline & est $+5 \mu$ moles Mo & 0 & 0 & 0 & 54 & 100 & 227 & 400 & 58 \\
\hline & d digest $+50 \mu$ mole & 0 & 33 & 33 & 76 & 133 & 167 & 446 & 631 \\
\hline \multirow[t]{3}{*}{$\mathrm{Cu}$} & d digest $+\mathrm{H}_{2} \mathrm{O}$ & 113 & 115 & 123 & 132 & 136 & 203 & 273 & 432 \\
\hline & rd digest $+5 \mu$ moles $\mathrm{Cu}$ & 210 & 0 & 46 & 227 & 416 & 768 & 854 & 90 \\
\hline & ard digest $+50 \mu$ moles $\mathrm{Cu}$ & 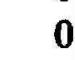 & 40 & 191 & 334 & 801 & 908 & 1,126 & 1,472 \\
\hline \multirow[t]{3}{*}{$\mathrm{Ca}$} & d digest $+\mathrm{H}_{2} \mathrm{O}$ & 153 & 140 & 116 & 110 & 126 & 254 & 429 & 62 \\
\hline & digest $+5 \mu$ mole & 176 & 162 & 147 & 142 & 147 & 285 & 540 & 69 \\
\hline & Standard digest $+50 \mu$ moles $\mathrm{Ca}$ & 127 & 127 & 136 & 153 & 196 & 309 & $\mathbf{5 7 8}$ & 68 \\
\hline \multirow[t]{3}{*}{ B } & Standard digest $+\mathrm{H}_{2} \mathrm{O}$ & 162 & 147 & 129 & 116 & 127 & 204 & 334 & 473 \\
\hline & Star & 136 & 125 & 126 & 127 & 136 & 240 & 367 & 546 \\
\hline & Standard digest +5 & 36 & 36 & 64 & 111 & 133 & 236 & 416 & 563 \\
\hline
\end{tabular}

1 The standard digest was composed of $0.5 \mathrm{ml}$. of acetate buffer ( $\mathrm{pH} 4.65), 0.5 \mathrm{ml}$ of substrate solution ( $0.05 \mathrm{M}$ or $0.10 \mathrm{M} \beta$-glycerophosphate), $0.25 \mathrm{ml}$. of $\mathrm{H}_{2} \mathrm{O}$ or arsenate solution, $0.25 \mathrm{ml}$. of variable additives, and $0.25 \mathrm{ml}$. of enzyme preparation containing 0.25 to $0.35 \mathrm{mg}$. of protein. All reactions were run for 20 minutes at $30^{\circ} \mathrm{C}$.

The standard arsenate curve was established at rates of 0 to $10 \mu$ moles per milliliter of digest. The added arsenate caused four- to sevenfold activity increases, depending upon the quantity of enzyme protein in the respective preparations. The inhibitors usually retarded phosphatase when 0 to 0.1 $\mu$ mole per milliliter of arsenate was present, and stimulated the reaction in the range of 6 to $10 \mu$ moles per milliliter of arsenate. Zinc, Mn, Mo, and $\mathrm{B}$ all behaved in this manner. Calcium and $\mathrm{Br}$ had little effect. Copper 
( $50 \mu$ moles per milliliter) induced the most outstanding phosphatase variations of the study, with complete inhibition at 0 arsenate and a greatly stimulated reaction at the high-arsenate level (fig. 5).

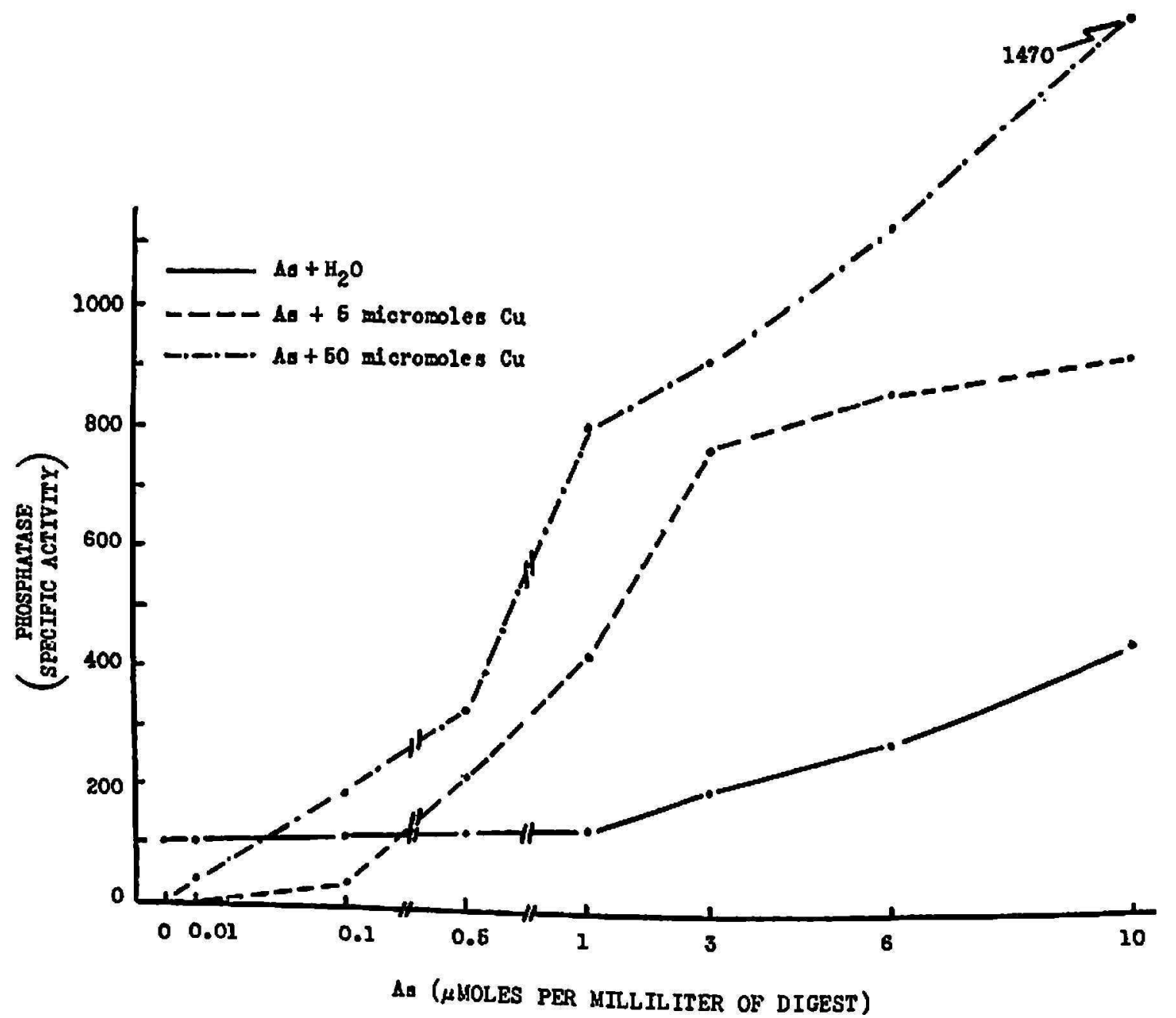

Fig. 5.-Effects of copper upon the arsenate-activated hydrolysis of $\beta$-glycerophosphoric acid by cane-leaf phosphatase.

\section{Molybdenum Inhibition vs. Calcium and Copper}

Particular attention was given to the effects of $\mathrm{Mo}, \mathrm{Ca}$, and $\mathrm{Cu}$ upon sugarcane acid phosphatase. Spencer (38) reported that Mo served as a competitive inhibitor of tomato acid phosphatases at concentrations as low as $10^{-7}$ molar sodium molybdate. Calcium is required for maximum activity of the apyrase of potato (17), and the ATP-ase activity of myosin and actomyosin (35). During earlier work with cauliflower ${ }^{4}$, the author observed interactions between $\mathrm{Ca}, \mathrm{Mo}$, and $\mathrm{Cu}$ upon phosphatase when these elements were supplied at variable concentrations in sand culture.

An Mo inhibition curve was established similar to that described for

${ }^{4}$ Unpublished Ph.D. thesis. 
arsenate activation, and the elements $\mathrm{Ca}$ and $\mathrm{Cu}$ were tested at variable levels against this curve (table 4).

Molybdenum strongly inhibited the phosphatase reaction at concentrations of 0.01 to $3.0 \mu$ moles per milliliter of digest. Calcium ( $50 \mu$ moles per milliliter) enhanced the inhibitory effects of $\mathrm{Mo}$, while $\mathrm{Cu}(50 \mu$ moles per milliliter) completely eliminated the low Mo inhibition and promoted phosphatase at the higher levels of Mo.

Molybdenum Inhibition vs. Calcium, Manganese, and Boron

In addition to the $\mathrm{Ca}$ and $\mathrm{Cu}$ effects mentioned above, two peculiar aspects of the Mo inhibition curve were readily evident (table 4). The lowest Mo concentration tested, $0.01 \mu$ mole per milliliter of digest, had so severely

TABLE 4.-Interacting effects of molybdenum, calcium, and copper upon the specific activity of acid phosphalase from sugarcane leaves ${ }^{2}$

\begin{tabular}{|c|c|c|c|c|c|c|c|c|c|}
\hline \multirow{2}{*}{ Expt. No. } & \multirow{2}{*}{ Treatment, $\mu$ moles $/ \mathrm{ml}$. of digest } & \multicolumn{8}{|c|}{ Mo, at $\mu$ moles $/ \mathrm{ml}$. of digest indicated- } \\
\hline & & 0 & 0.01 & 0.1 & 0.5 & 1 & 3 & 6 & 10 \\
\hline \multirow[t]{3}{*}{1} & Standard digest $+\mathrm{H}_{2} \mathrm{O}$ & 109 & 24 & 11 & 24 & 0 & 0 & 34 & 131 \\
\hline & Standard digest $+5 \mu$ moles $\mathrm{Ca}$ & 93 & 31 & 11 & 11 & 11 & 0 & 33 & 131 \\
\hline & Standard digest $+50 \mu$ moles $\mathrm{Ca}$ & 94 & 11 & 0 & 0 & 0 & 0 & 36 & 104 \\
\hline \multirow[t]{3}{*}{2} & Standard digest $+\mathrm{H}_{2} \mathrm{O}$ & 96 & 24 & 22 & 24 & 24 & 11 & 38 & 134 \\
\hline & Standard digest $+5 \mu$ moles $\mathrm{Cu}$ & 100 & 33 & 51 & 40 & 54 & 40 & 89 & 211 \\
\hline & Standard digest $+50 \mu$ moles $\mathrm{Cu}$ & 236 & 464 & 387 & 314 & 464 & 327 & 651 & 747 \\
\hline
\end{tabular}

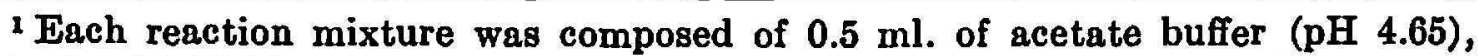
$0.5 \mathrm{ml}$. of $0.05 \mathrm{M} \beta$-glycerophosphate, $0.25 \mathrm{ml}$. of water or additive solution, and $0.25 \mathrm{ml}$. of enzyme preparation. Each reaction proceeded for 20 minutes at $30^{\circ} \mathrm{C}$.

inhibited the reaction that in all probability a significant inhibition could have been obtained with far less quantities of Mo. On the other hand, Mo concentrations as high as 30 and $50 \mu$ moles per milliliter appeared to reverse the low Mo inhibition, and increased phosphatase activity beyond control levels. Both observations were further analyzed in detail.

Experiments were conducted with variable $\mathrm{Ca}, \mathrm{Mn}$, and $\mathrm{B}$ against an Mo inhibition curve which was lowered to include an Mo level of 0.0001 $\mu$ mole per milliliter of digest (table 5). It was interesting to note that $0.0001 \mu$ mole of Mo per milliliter caused an inhibition of about 35 percent. Manganese, which is an essential activator of yeast ATP-ase (25), slightly increased the Mo inhibition at $2 \mu$ moles of $\mathrm{Mn}$ per milliliter, and strongly enhanced the Mo effects at $20 \mu$ moles of Mn per milliliter of digest (fig. 6). Boron, at 5 and $50 \mu \mathrm{moles} / \mathrm{ml}$., promoted the Mo effects in a manner identical with that of $\mathrm{Mn}$. 


\section{Molybdenum Activation vs. Copper and Arsenate}

The activating effects of $\mathrm{Cu}$ and arsenate have thus far been described only in the absence of Mo. After observing the apparent activating effects of Mo at high concentrations, additional experiments were run to determine the effects of $\mathrm{Cu}$ and arsenate in the presence of Mo levels ranging from 0.001 to $100 \mu$ moles per milliliter of digest (figs. 7 and 8).

Molybdenum achieved its maximum stimulating effects between 50 and $70 \mu$ moles per milliliter of digest, when acting in the absence of other addi-

TABLE 5.-Effects of variable calcium, manganese, and boron upon the specific activity of sugarcane-leaf phosphatase, in the presence of inhibitory levels of molybdenum ${ }^{1}$

\begin{tabular}{|c|c|c|c|c|c|c|c|c|c|}
\hline \multirow{2}{*}{ Element } & \multirow{2}{*}{ Treatment, $\mu$ moles $/ \mathrm{ml}$, of digest } & \multicolumn{8}{|c|}{ Mo, $\mu \mathrm{moles} / \mathrm{ml}$. of digest indicated- } \\
\hline & & $\mathbf{0}$ & 0.001 & 0.005 & 0.01 & 0.03 & 0.06 & 0.1 & 0.3 \\
\hline \multirow[t]{4}{*}{$\mathbf{C a}$} & Standard digest $+\mathrm{H}_{2} \mathrm{O}$ & 146 & 105 & 47 & 32 & 25 & 14 & 12 & 10 \\
\hline & Standard digest $+0.5 \mu$ mole $\mathrm{Ca}$ & 142 & 104 & 47 & 34 & 19 & 13 & 12 & 11 \\
\hline & Standard digest $+5 \mu$ moles $\mathrm{Ca}$ & 153 & 100 & 46 & 32 & 19 & 12 & 12 & 11 \\
\hline & Standard digest $+50 \mu$ moles $\mathrm{Ca}$ & 138 & 92 & 46 & 32 & 18 & 13 & 12 & 11 \\
\hline \multirow[t]{4}{*}{$\mathbf{M n}$} & Standard digest $+\mathrm{H}_{2} \mathrm{O}$ & 193 & 146 & 68 & 39 & 22 & 17 & 13 & $\longrightarrow$ \\
\hline & Standard digest $+0.2 \mu$ mole $\mathrm{Mn}$ & 193 & 140 & 64 & 34 & 22 & 16 & 13 & 一 \\
\hline & Standard digest $+2 \mu$ moles $\mathrm{Mn}$ & 138 & 115 & 53 & 33 & 21 & 16 & 13 & - \\
\hline & Standard digest $+20 \mu$ moles $\mathrm{Mn}$ & 32 & 32 & 24 & 19 & 15 & 12 & 10 & - \\
\hline \multirow[t]{4}{*}{ B } & Standard digest $+\mathrm{H}_{2} \mathrm{O}$ & 164 & 109 & 54 & 31 & 19 & 13 & 12 & - \\
\hline & Standard digest $+0.5 \mu$ mole B & 154 & 112 & 47 & 32 & 19 & 13 & 12 & - \\
\hline & Standard digest $+5 \mu$ moles $B$ & 129 & 104 & 47 & 28 & 19 & 14 & 12 & - \\
\hline & Standard digest $+50 \mu$ moles $B$ & 58 & 46 & 32 & 22 & 15 & 11 & 10 & \\
\hline
\end{tabular}

1 Each reaction mixture was composed of $0.5 \mathrm{ml}$. of acetate buffer ( $\mathrm{pH} \mathrm{4.65),0.5}$ $\mathrm{ml}$. of $0.05 \mathrm{M} \beta$-glycerophosphate, $0.25 \mathrm{ml}$. of water or additive solution, and 0.25 $\mathrm{ml}$. of enzyme preparation. Each reaction proceeded for 20 minutes at $30^{\circ} \mathrm{C}$.

2 The $0.3 \mu$ mole of Mo treatment was not included in the $\mathrm{Mn}$ and B experiments.

tives. The addition of $10 \mu$ moles per milliliter of $\mathrm{Cu}$ caused the activation to begin at $30 \mu$ moles of Mo, and to continue linearly to $100 \mu$ moles of Mo per milliliter of digest (fig. 7). Added $\mathrm{Cu}$ intensified the inhibitory effects of low Mo. Arsenate simply stimulated the entire Mo inhibition-activation curve into a vastly higher plane, while both types of Mo effects were still portrayed by the shape of the curve (fig. 8). The implication here is that arsenate acts independently of Mo, and that there is no competition between the two elements for the reactive sites at which Mo effects occur.

\section{Inhibition of Phosphatase by Tungsten}

An investigator might experiment indefinitely with potential inhibitors and activators of a partly purified enzyme preparation. However, three 


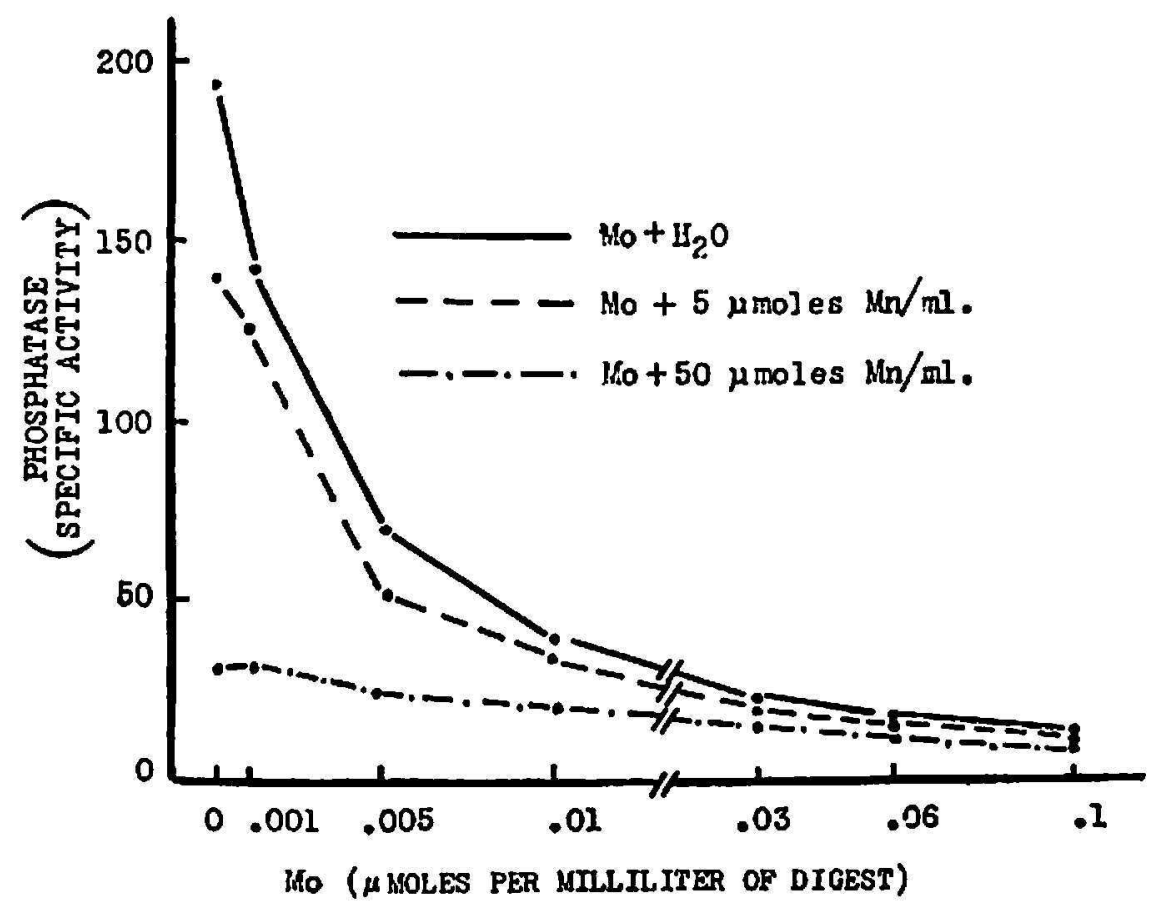

FIg. 6.-Effects of variable manganese upon the response of sugarcane-leaf phosphatase to inhibitory concentrations of molybdenum.

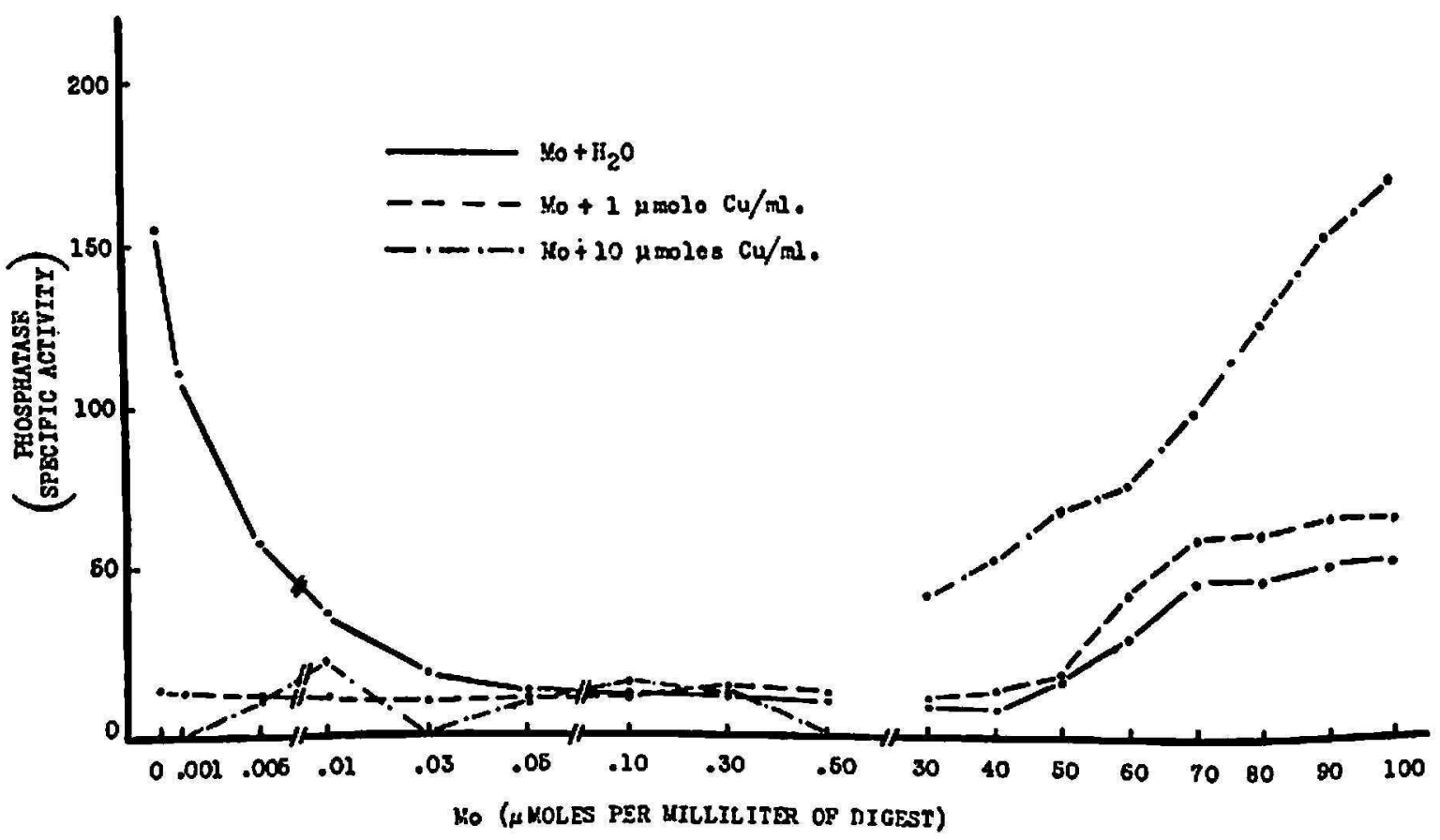

Fig. 7.-Effects of variable copper upon the response of sugarcane-leaf phosphatase to extremely low and high levels of molybdenum.

additional reagents fell with the scope of this study, including glucose, iron (Fe), and tungsten (W).

Glucose is known to be a competitive inhibitor of the phosphorylase of muscle (8) and potato (13). Evidence has also been published showing that 
animal phosphorylase is inactivated by a specific phosphatase (28). Since we had already observed a general increase of glucose coupled with stimulated phosphatase and decreased starch phosphorylase in sugarcane (2), the possibility that glucose was involved in the phosphatase stimulation could not be overlooked.

Iron was selected on the basis of the author's past observations that Mo interfered with the $\mathrm{Fe}$ activation of peroxidase and catalase in cauliflower ${ }^{5}$. It was felt that $\mathrm{Fe}$ might, in turn, possess properties enabling it to interfere with the Mo effects upon phosphatase.

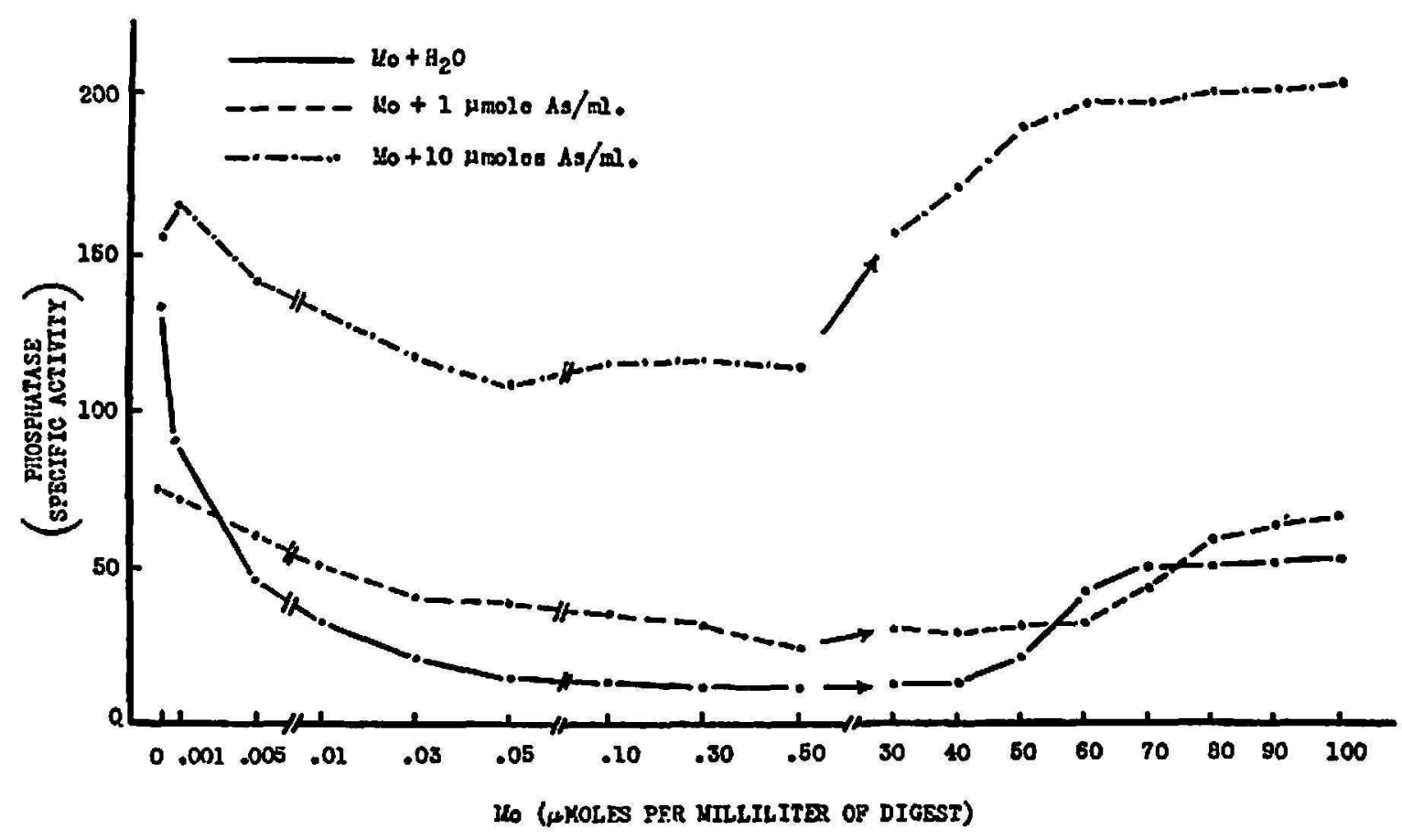

Fig. 8.-Effects of variable arsenate upon the response of sugarcane-leaf phosphatase to extremely low and high levels of molybdenum.

Tungsten was selected for study on the basis of its close physical and chemical similarity to Mo. In the pure state, both W and Mo are extremely hard metals, with high melting points and bright, silvery luster. Both metals form important compounds in the valence state of +6 , including the trioxides $\mathrm{MoO}_{3}$ and $\mathrm{WO}_{3}$. Both metals enter into reactions via the divalent anions ( $\mathrm{WO}_{4}^{-}-$and $\mathrm{MoO}_{4}^{--}$), and we were therefore curious to learn whether or not $W$ could induce enzymatic effects such as those already known for Mo.

A series of phosphatase tests was run against glucose concentrations of 0.05 to $50 \mu$ moles per milliliter, Fe concentrations of 0.01 to $10 \mu$ moles per milliliter, and $\mathrm{W}$ from 0.01 to $10 \mu$ moles per milliliter of digest. Glucose and

5 Unpublished Ph.D. thesis. 
Fe had no effects. Surprisingly, not a trace of phosphatase could be detected in any of the $W$ tests, indicating that $0.01 \mu$ mole per milliliter of the element was causing 100-percent inhibition.

Additional experiments were conducted in which phosphatase was exposed to $\mathrm{W}$ levels of 0.0001 to $0.1 \mu$ mole per milliliter of digest (fig. 9). The reaction was suppressed to 40 percent of controls by the incredibly low $W$ level of $0.0001 \mu \mathrm{mole}$ per milliliter. Comparison of these results with Mo inhibition data showed that $W$ was apparently suppressing phosphatase

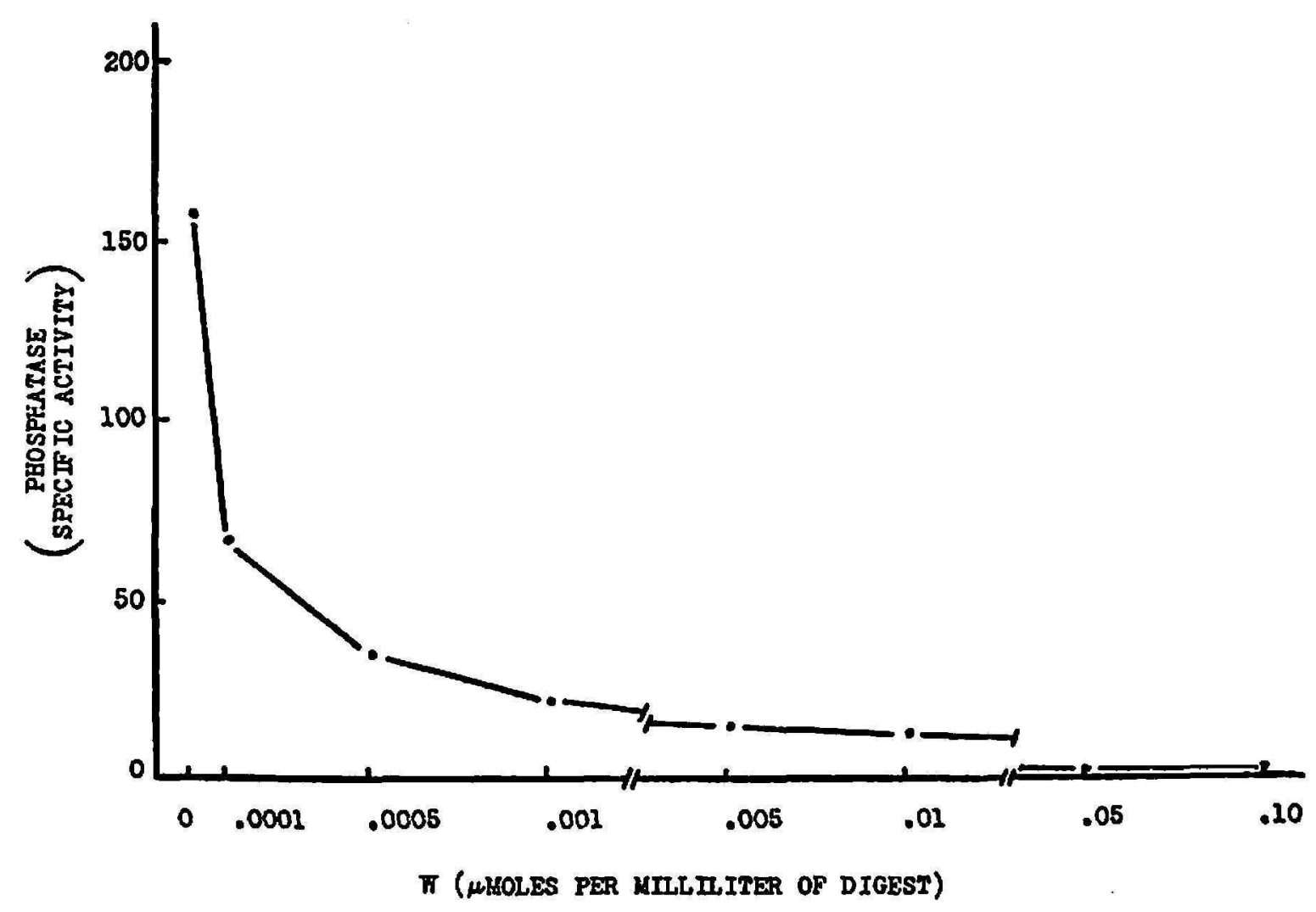

Fic. 9.-Inhibitory effects of tungsten upon sugarcane-leaf phosphatase.

in concentrations somewhat below that required by Mo. The two elements were therefore compared simultaneously at concentrations ranging from 0.0001 to $0.01 \mu$ mole per milliliter of digest. Figure 10 illustrates that above $0.0005 \mu$ mole per milliliter, $W$ was inhibiting phosphatase at concentrations $1 / 6$ to $1 / 10$ of that required by Mo to achieve the same effect. For example, 75-percent inhibition was obtained with $0.001 \mu$ mole per milliliter of $W$, while the same response required $0.01 \mu$ mole per milliliter of Mo. When ATP was employed as substrate, the inhibitory action of Mo and W was more nearly comparable, with Mo being slightly more effective than $W$ (fig. 11). 


\section{Molybdenum and Tungsten as Competitive Inhibitors of Phosphatase}

Spencer (33) demonstrated that the inhibitory effect of Mo on tomato acid phosphatase was competitive (reversible), by eliminating the inhibition through use of increased substrate concentrations. It was suspected that Mo and $W$ were competitively inhibiting the phosphatase of cane, and therefore both elements were tested against substrate concentrations ranging from 10 to $400 \mu$ moles of $\beta$-glycerophosphate per milliliter of digest. Molybdenum inhibition was found to be characteristic of the competitive

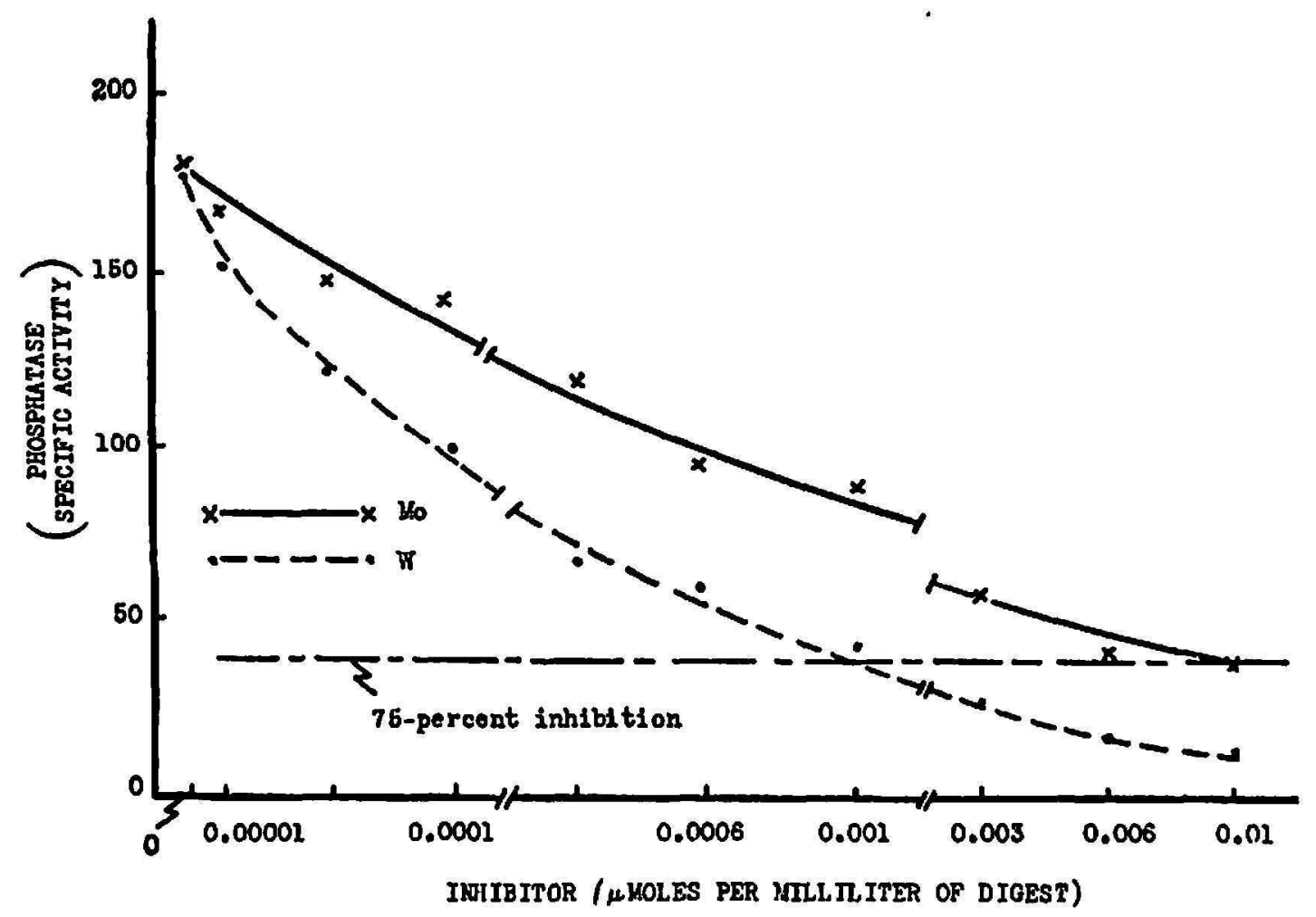

Fra. 10.-Inhibitory effects of molybdenum and tungsten upon the $\beta$-glycerophosphate-hydrolyzing activity of cane-leaf phosphatase preparation.

type, and was 90 -percent eliminated by a tenfold increase in $\beta$-glycerophosphate (fig. 12).

It is evident, however, that the Mo reaction was not entirely competitive, i.e., plotting the reciprocals of both initial velocity and substrate concentrations, according to the method of Lineweaver and Burk (21), yields lines of differing slope which do not intercept on the $y$ axis. The substrate itself became inhibitory above $200 \mu$ moles per milliliter. Repeated tests with substrate levels between 100 and $200 \mu$ moles per milliliter failed to remove more than 90 percent of the inhibition, and it was concluded that about 10 percent of the $\beta$-glycerophosphate reaction was of a nonreversible 


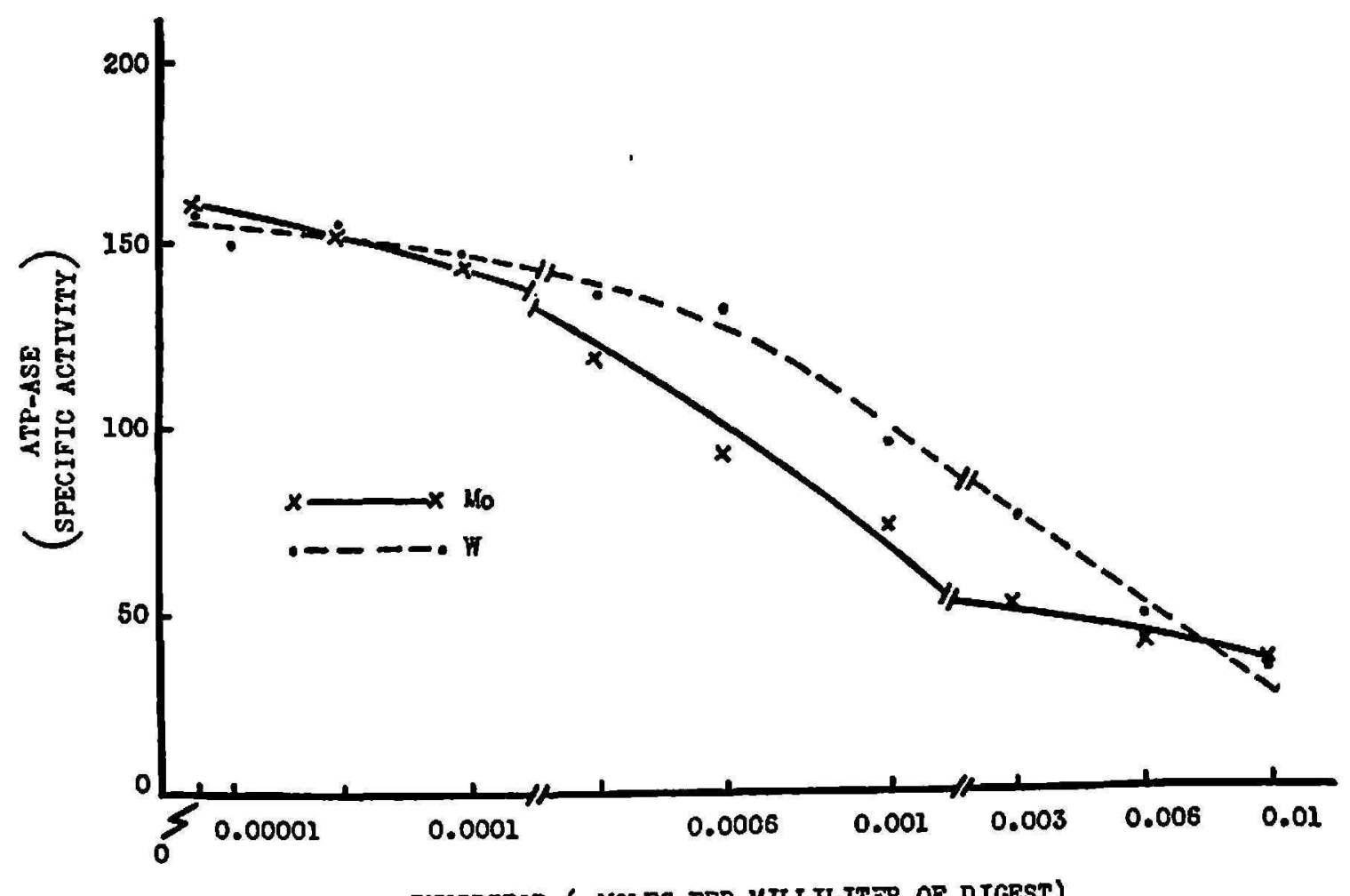

INHIBITOR ( $\mu$ MOLES PER XILLILITAR OF DIGEST)

FIG. 11.-Inhibitory effects of molybdenum and tungsten upon the ATP-hydrolyzing activity of cane-leaf phosphatase preparation.

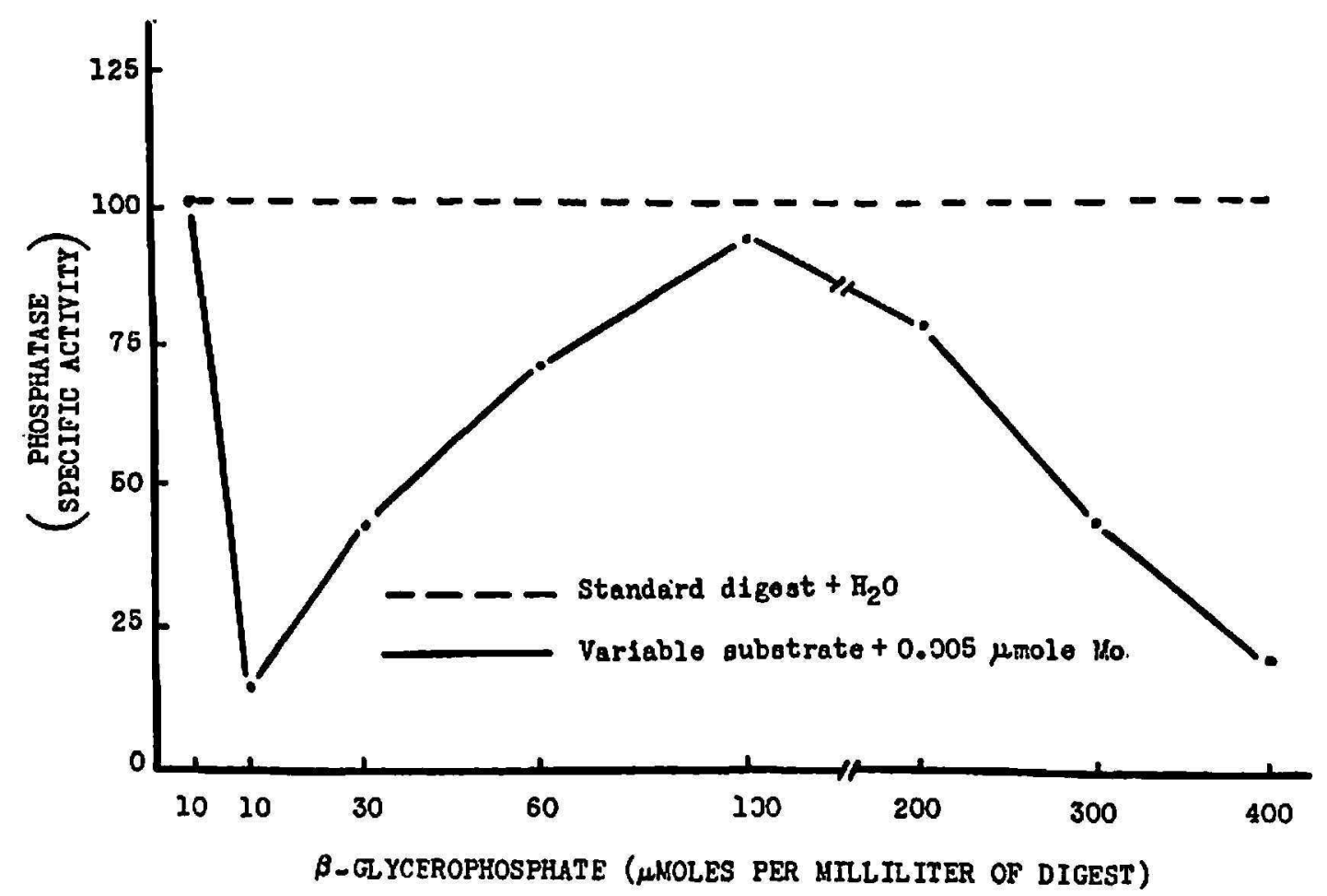

Fig. 12.-Effects of variable substrate concentration upon the response of sugarcane-leaf phosphatase to an inhibitory level of molybdenum. 
type. Complete reversal of the $\mathrm{W}$ inhibition was achieved with $200 \mu$ moles per milliliter of $\beta$-glycerophosphate (fig. 13).

\section{Mode of Action by Phosphatase Activators and Inhibitors}

The observation that a given element may serve as an activator of one enzyme and an inhibitor of another is fairly common in enzymology. Molybdenum, for example, in addition to inhibiting phosphatase, serves as an essential cofactor for the activation of nitrate reductase (11). More difficult to explain is the inhibitory effect of an element upon an enzyme at one

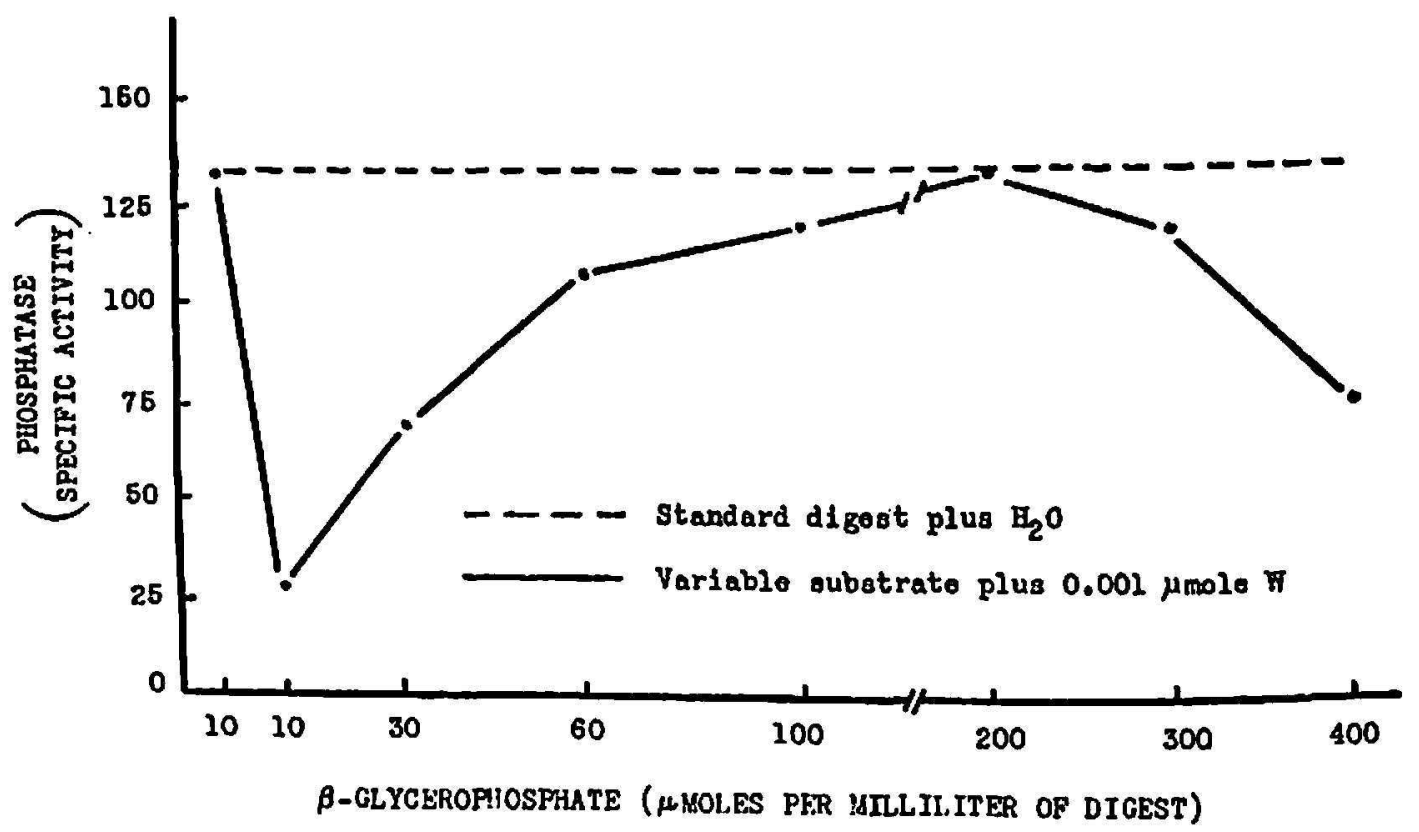

Fig. 13.-Effects of variable substrate concentration upon the response of caneeaf phosphatase to an inhibitory level of tungsten.

1

concentration, and its activating effects upon the same enzyme at another concentration.

In the instance of the Mo inhibition and activation of sugarcane phosphatase, we assume that at least two types of reactive sites are involved. One type is apparently present on the enzyme itself, in limited number, and requires a very specific ion in order to be blocked. A second type of reactive site must be present at which numerous activators and inhibitors are accepted, and the mass action of such additives as Mo tends to remove the sites from the action of more severe inhibitors. The ability of Mo to exist in compounds with valence states of +2 to +5 , inclusive, would suit this element admirably for such multiple roles. We feel that the "activating" effect of high Mo was not the response of a true activator, which should never be required in quantities of 50 to $100 \mu$ moles per milliliter, but rather exemplifies a readjustment of ionic ratios less favorable to other inhibitors. 
An obvious weakness of this assumption is the fact that, no matter how much Mo was present for mass action against other inhibitors, some small percentage of that fraction should still be available to inhibit phosphatase in the manner noted for only traces of Mo.

To our knowledge, the best review available concerning special cases of enzyme activation and inhibition is presented in chapter 10 of John M. Reiner's Behavior of Enzyme Systems (29). His discussion concerning enzyme stimulation by inhibitors is particularly applicable to the inhibitoractivator relationships observed with sugarcane phosphatase. The appropriate concepts are treated extensively in mathematical terms, but they can be summarized as follows:

1. PROTECTIVE InHIBITION.-Assuming that a given protein is at all times undergoing some denaturation, and that the denaturation is reversible, it is shown that under conditions of partial inhibition an inhibitor may act as a stimulator, provided that the denaturation effect is sufficiently pronounced. The primary concern here is with the balance between inhibitory and protective aspects of a compound, with the importance of the protective effect depending upon the need for protection.

2. INHIBITOR AS ANTI-INHIBITOR.-Under conditions whereby a given compound may inhibit an enzyme by one mechanism, and also combine with or destroy another inhibitor of that enzyme, it is shown that such a compound may stimulate the enzyme under a limited range of conditions.

3. NEUTRAL ANTI-INHIBITORS AS ACTIVATORS.-A neutral compound, one which has no interaction with enzyme, substrate, or other activators of the enzyme, may serve to activate by removing inhibitors.

4. PARTIAL INHIBITOR AS ANTI-INHIBITOR.-The same mechanism outlined above under point No. 1, whereby an inhibitor stimulated by protecting the enzyme against denaturation, will also permit a partial inhibitor to protect the enzyme against another inhibitor.

We feel that the Mo inhibitor-activator effects upon sugarcane phosphatase can best be classified under point No. 2. Point No. 3 is also applicable to the extent that Mo did not in itself react with enzyme, substrate, or activators. However, the versatile chemical properties of Mo, its profound effects upon phosphatase in mere traces, and the known requirement of Mo as a cofactor of certain plant enzymes, all suggest that it was not likely acting as a neutral entity.

Perhaps of more significance than the specific mode of inhibitor action is the fact that sugarcane phosphatase was inhibited by elements commonly regarded as essential for the plants' welfare, and yet are almost never considered in the light of their effects upon sugarcane enzymes. The elements $\mathrm{Cu}, \mathrm{B}, \mathrm{Mn}, \mathrm{Zn}$, and Mo are all known to be essential for normal plant growth and development. As such, it is only a matter of time until nutri- 
tion technology has advanced to a point where one or more of these elements will be supplied as supplements in order to promote maximum sugar production. Arsenate has long been received by agricultural soils as a consequence of pesticide programs. Tungsten may be excluded for the moment from both micronutrient compositions and pesticide materials. However, on the basis of its close similarity to Mo, and its striking effects upon the sugarcane phosphatases, we feel that it is only a matter of time until W will also be regarded as an essential element for plants, very likely as a constituent of enzymatic reactions.

TABLE 6.-Phosphatase specific activily and percentages of the total phosphatase product by variable tissue from 10-month-old sugarcane ${ }^{1}$

\begin{tabular}{|c|c|c|c|c|c|c|c|c|}
\hline \multirow[b]{2}{*}{ Substrate } & \multirow[b]{2}{*}{ Data classification } & \multicolumn{7}{|c|}{ Data for enzyme source indicated- } \\
\hline & & $\begin{array}{l}\text { Mer- } \\
\text { istem }\end{array}$ & $\begin{array}{c}\text { Leaves } \\
-1 \\
\text { and } 0\end{array}$ & $\begin{array}{c}\text { Leaves } \\
+2 \text { and } \\
+3\end{array}$ & $\begin{array}{l}\text { Leaves } \\
+5 \text { and } \\
+6\end{array}$ & $\begin{array}{c}\text { Sheaths } \\
+5 \text { and } \\
+6\end{array}$ & $\begin{array}{l}\text { Inter- } \\
\text { nodes } \\
8 \text { to } 10\end{array}$ & $\begin{array}{l}\text { Nodes } \\
8 \text { to } 10\end{array}$ \\
\hline $\begin{array}{l}\beta \text {-Glycero- } \\
\text { phosphate }\end{array}$ & $\begin{array}{l}\text { Specific activity } \\
\text { Percentage of to- } \\
\text { tal product }\end{array}$ & $\begin{array}{c}148 \\
23.2\end{array}$ & $\begin{array}{l}89 \\
18.8\end{array}$ & $\begin{array}{l}43 \\
14.5\end{array}$ & $\begin{array}{l}30 \\
9.1\end{array}$ & $\begin{array}{l}45 \\
10.9\end{array}$ & $\begin{array}{r}138 \\
7.6\end{array}$ & $\begin{array}{l}91 \\
15.9\end{array}$ \\
\hline ATP & $\begin{array}{l}\text { Specific activity } \\
\text { Percentage of to- } \\
\text { tal product }\end{array}$ & $\begin{array}{c}161 \\
22.7\end{array}$ & \begin{tabular}{|l|}
88 \\
16.6
\end{tabular} & $\begin{array}{l}56 \\
16.9\end{array}$ & $\begin{array}{l}41 \\
11.0\end{array}$ & $\begin{array}{l}48 \\
10.4\end{array}$ & $\begin{array}{c}160 \\
7.8\end{array}$ & $\begin{array}{l}93 \\
14.6\end{array}$ \\
\hline
\end{tabular}

1 Each reaction mixture was composed of $0.5 \mathrm{ml}$. of acetate buffer ( $\mathrm{pH} 4.65$ ), 0.5 $\mathrm{ml}$. of substrate solution $(0.05 \mathrm{M})$, and $0.25 \mathrm{ml}$. of enzyme preparation. All reactions were run for 20 minutes at $30^{\circ} \mathrm{C}$.

\section{EFFECTS OF DIALYSIS}

Samples of the phosphatase preparation were dialyzed against distilled water for periods ranging up to 26 hours. Two-hour treatment caused slight increases in activity. Prolonged dialysis caused no additional changes.

\section{PHOSPHATASE FROM VARIOUS TISSUE SOURCES}

Sugarcane is composed of many diverse tissues and it is virtually impossible to conduct a prolonged study with enzyme preparations from all areas of the plant. We have generally regarded leaves +1 to +4 as bearing the most indicative fraction of a given sugarcane enzyme, and although this assumption is not always correct, it is seldom misleading.

The ATP and $\beta$-glycerophosphate reactions were composed with phosphatase from meristem, leaf, sheath, node, and internode tissues of 10months-old sugarcane (table 6). All samples were prepared in a manner identical to that already described for leaves. Among the tissues tested, both the ATP and $\beta$-glycerophosphate reactions were greatest with the 
meristem and 8- to 10-internode preparations. Lowest specific activity was recorded for enzymes from leaves +5 and +6 . These figures in themselves are misleading, however, because so little protein was present in 8 to 10 internodes that the actual phosphatase product of that sample was the lowest recorded. Meristem tissue was the richest phosphatase source, both from the standpoint of specific activity and percentage of total phosphatase product.

\section{SIGNIFICANCE OF SUGARCANE PHOSPHATASE}

The acid phosphatases must be classified as one of the most important groups of enzymes in cane, if for no other reason than because of the voraciousnous with which they hydrolyze the phosphorylated precursors of sucrose. At this writing we have measured the reaction against glucose-1phosphate, glucose-6-phosphate, fructose-6-phosphate, fructose-1,6-diphosphate, 3-phosphoglyceric acid, 2-phosphoglyceric acid, ATP, ADP, UTP, and UDPG. Any one of these reactions could be a limiting factor against sucrose production or normal plant respiration. The phosphatases undoubtedly exact their toll of any pathway, product, or function whose successful maintenance depends upon phosphorylated intermediates.

The acid phosphatases would rank high in importance if they attacked no other compound than ATP. As a source of energy and inorganic phosphorus, ATP is safely regarded as one of the most critical biological compounds known. Some of the biochemical reactions for which an ATP involvement is claimed include muscular contraction $(10,27)$, lactic acid formation $(35$, p. 349$)$, the phosphorylation of thiamine $(19,37)$, the phosphorylation of carboxyl groups with the subsequent easing of their reduction (20), the formation of peptide bonds (7), fatty acid oxidation (18), fatty acid synthesis (34), action of growth substances (4, p. 459), amide formation (32), and sucrose synthesis $(4$, p. 40).

Not all phosphatase reactions are of a negative or limiting character. Meyerhof (24), for example, demonstrated that the glucose metabolism of yeast requires an active ATP-ase to maintain a balance between the phosphorylation of glucose, for which ATP is required, and the phosphorylation of glyceraldehyde-3-phosphate, for which inorganic phosphorous is required. Buchanan (6) reported that phosphatase takes part in the production of sucrose from the sucrose phosphate of sugar beet.

Evidence is available that fructose-6-phosphate, in addition to free fructose, may serve as the acceptor of glucose during the final stages of sucrose formation $(9)$ :

$$
\text { UDPG + Fructose-6-P } \rightarrow \text { Sucrose-phosphate + UDP }
$$

It is also evident that excessive phosphatase of the monoesterase type 
would deplete fructose-6-phosphate before it could enter the UDPG transglycosylase reaction, and a strongly inhibited phosphatase would tend to leave part of the sucrose in the form of a phosphate ester. We must conclude that both excessively high and excessively low phosphatase reactions may have serious consequences to the cane plant.

\section{SUMMARY}

Acid phosphatases which readily hydrolyzed components of the adenylic acid system and phosphate monoesters were precipitated from cane-leaf extracts between 48- and 58-percent saturation with ammonium sulfate. The two general types were distinguished by their response to variable $\mathrm{pH}$, substrate concentration, temperature, and inhibitors. ATP and $\beta$-glycerophosphate were employed as representative substrates for the two groups.

Both types of phosphatase were stimulated by arsenate. The $\beta$-glycerophosphate reaction was inhibited by boron, zinc, manganese, bromide, copper, molybdenum, and tungsten. Molybdenum and tungsten also inhibited the ATP reaction. None of the inhibitors was effective in the presence of $10 \mu$ moles per milliliter of arsenate. Copper appeared to serve as an activator in the presence of arsenate.

Molybdenum and tungsten acted as competitive inhibitors of phosphatase. Molybdenum severely inhibited the $\beta$-glycerophosphate reaction at $0.001 \mu$ mole per milliliter of digest, whereas 50 to $70 \mu$ moles caused much of the activity to return. Both molybdenum and tungsten caused significant inhibition at concentrations as low as $0.0001 \mu$ mole per milliliter of digest. Tungsten was more effective than molybdenum against the $\beta$-glycerophosphate reaction, causing significant suppression at concentrations $1 / 6$ to $1 / 10$ of the molybdenum levels needed for a comparable inhibition.

Dialysis against distilled water had no appreciable effect on the phosphatase preparation. Meristem tissue was the best source of phosphatase, both in terms of specific activity and total phosphatase product.

The possible mode of action of the inhibitor-activator relationships, and the significance of acid phosphatases in cane, is briefly discussed.

\section{RESUMEN}

Se precipitaron con sulfato amónico fosfatasas ácidas de extractos de la hoja de la caña de azúcar con una saturación de 48 a 58 por ciento. Estas fosfatasas hidrolizaron con rapidez los componentes del sistema ácido adenílico y los monoesteres de fosfato. Los dos tipos generales de fosfatasas se identificaron por su reacción a un $\mathrm{pH}$ variable, a la concentración de substrato, a la temperatura y a los agentes inhibidores. Se usaron el ATP y el glicerofosfato-beta como substratos representativos para los dos grupos.

Ambos tipos de fosfatasas se estimularon con arseniato. El boro, el zinc, 
el manganeso, el bromuro, el cobre, el molibdeno y el tungsteno inhibieron la reacción del glicero-fosfato- $\beta$. El molibdeno y el tungsteno también inhibieron la reacción del ATP. Ninguno de los agentes inhibidores causó efecto alguno en presencia de $10 \mu \mathrm{moles} / \mathrm{ml}$. de arseniato, en cambio, en presencia de arseniato, el cobre pareció actuar como un activador.

El molibdeno y el tungsteno compitieron como agentes inhibidores de la fosfatasa. El molibdeno inhibió en extremo la reacción del glicerofosfato$\beta$ en un digesto al $0.001 \mu \mathrm{mole} / \mathrm{ml}$., aunque de 50 a $70 \mu$ moles bastaron para restituir la actividad en gran medida. Tanto el molibdeno como el tungsteno causaron una inhibición significativa a concentraciones tan bajas como $0.0001 \mu \mathrm{mole} / \mathrm{ml}$. del digesto. El tungsteno fue más efectivo que el molibdeno en inhibir la acción del glicerofosfato- $\beta$, causando una supresión significativa a concentraciones de $1 / 6$ a $1 / 10$ de los niveles de molibdeno que se necesitan para una inhibición comparable.

La diálisis en presencia de agua destilada no tuvo efecto apreciable sobre la preparación de la fosfatasa. El tejido meristémico fue la fuente mejor de fosfatasa, tanto en términos de actividad específica, como de producción total de fosfatasa.

También se discute brevemente el posible mecanismo de las relaciones entre los agentes inhibidores y los activantes, $y$ lo que significan las fosfatasas ácidas en la caña.

\section{LITERATURE CITED}

1. Alexander, A. G., Sucrose-enzyme relationships in immature sugarcane as affected by variable nitrate and potassium supplied in sand culture, J. Agr. Univ. P.R. 48 (3): 165-231, 1964.

2. - Behavior of enzymes governing starch-and sucrose-forming pathways in two sugarcane varieties supplied with variable nitrate and phosphate in sand culture, J. Agr. Univ. P.R. 49 (2): 153-75, 1965.

3. Axelrod, B., and Jagendorf, A. T., The fate of phosphatase, invertase, and peroxidase in autolyzing leaves, Plant Physiol. 26: 406-10, 1951.

4. Bonner, J., Plant Biochemistry, Academic Press Inc., New York, N.Y., 1950.

5. Bossard, M., Action of molybdates on various enzymes, B. Soc. Chem. Biol. 29: 218-21, 1947.

6. Buchanan, J. G., The path of carbon in photosynthesis, XIX, The identification of sucrose phosphate in sugar beet leaves, Arch. Biochem. \& Biophys. 44: 140-9, 1953.

7. Cohen, P. P., and McGilvery, R., Peptide bond synthesis, $I$, The formation of $p$-aminohippuric acid by rat liver slices, $J$. Biol. Chem. 166: 261-72, 1946; II, The formation of $p$-aminohippuric acid by liver homogenate, 169: 119-36, 1947; III, On the mechanism of $p$-aminohippuric acid synthesis, $171: 121-33,1947$.

8. Cori, G. T., and Cori, C. F., The kinetics of the enzymatic synthesis of glycogen from glucose-1-phosphate, J. Biol. Chem. 185: 733-56, 1940.

9. Dugger, W. M., and Humphreys, T. E., Influence of boron on enzymatic reactions associated with biosynthesis of sucrose, Plant Physiol. 35: 523-30, 1960. 
10. Engelhardt, V. A., Adenosinetriphosphatase properties of myosine, Advn. in Enzymol. 6: 147-90, 1946.

11. Evans, H. J., Role of molybdenum in plant nutrition, Soil Sci. 81: 199-208, 1956.

12. Fruton, J. S., and Simmonds, S., General Biochemistry, John Wiley \& Sons, Inc., New York, N.Y., 1959.

13. Hanes, C. S., Reversible formation of starch from glucose-1-phosphate catalyzed by potato phosphorylase, Proc. Roy. Soc. London, B 129: 174-9, 1940.

14. Heppel, L. A., and Hilmore, R. J., Purification of yeast inorganic pyrophosphatase, J. Biol. Chem. 192: 87-94, 1951.

15. Ignatief, V., and Wasteneys, H., Phosphatase distribution in some higher plants, Biochem. J. S0: 1171-82, 1936.

16. Kalchar, H. M., Adenylpyrophosphatase and myokinase, J. Biol. Chem. 158: 355-67, 1944.

17. Krishnan, P. S., Studies on apyrases, I, Purification of potato apyrase by fractional precipitation with ammonium sulfate, Arch. Biochem. 20: 261-71, 1949.

18. Lehninger, A. L., Fatty acid oxidation and the Krebs tricarboxylic acid cycle, J. Biol. Chem. 161: 413-4, 1945.

19. Lipmann, F., and Tuttle, L. C., A specific micromethod for the determination of acyl phosphates, J. Biol. Chem. 159: 21-8, 1945.

20. Lipmann, F., Metabolic generation and utilization of phosphate bond energy, Adon. in Enzymol. 1: 99-152, 1941.

21. Lineweaver, H., and Burk, D., The determination of enzyme dissociation constants, $J$. Amer. Chem. Soc. 56: 658-66, 1934.

22. Massart, L., and Vermeyen, K., Inhibitors of potato phosphatase, Nat.wiss. schaften so: 170, 1942.

23. Meyerhof, $O$., The origin of the reaction of Harden and Young in cell-free alcoholic fermentation, J. Biol. Chem. 157: 105-19, 1945.

24. - Further studies on the Harden-Young effect in alcoholic fermentation of yeast preparations, $J$. Biol. Chem. 180: 575-86, 1949.

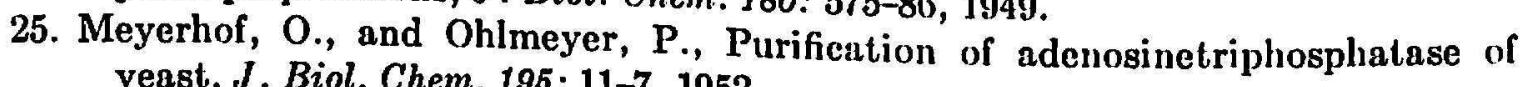
yeast, J. Biol. Chem. 195: 11-7, 1952. 26. Neilands, J. B., and Stumpf, P. K., Outlines of Enzyme Chemistry, John Wiley
\& Sons, Inc., New York, N.Y., 1955.

27. Perry, S. V., The adenosinetriphosphate activity of myofibrils isolated from skeletal muscle, Biochem. J. 48: 257-65, 1951.

28. Rall, T. W., Sutherland, E. W., and Wosilait, W. D., The relationship of epinephrine and glucagon to liver phosphorylase, III, Reactivation of liver phosphorylase in slices and extracts, J. Biol. Chem. 218: 483-96, 1956. 29. Reiner, J. M., Behavior of Enzyme Systems, Burgess Publishing Co., Minneapolis
15, Minn., 1959.

30. Robison, R., and Soames, K. M., Possible significance of hexosediphosphoric esters in ossification, II, Phosphoric esterase of ossifying cartilage, Biochem.
$J .18: 740-54,1024$.

31. Rothstein, A., and Meier, R., The relationship of the cell surface to metabolism, IV, The role of cell surface phosphatases of yeast, J. Cell. Compar. Physiol. 34: 97-114, 1949.

32. Speck, J. F., The enzymatic synthesis of glutamine, J. Biol. Chem. 168: 403-4, 1947.

33. Spencer, D., The effect of molybdate on the activity of tomato acid phosphatases, Austral. J. Biol. Sci. 7: 151-60, 1954. 
34. Stadtman, E. R., Stadtman, T. C., and Barker, H. A., Tracer experiments on the mechanism of synthesis of valeric and caproic acids by Clostridium kluyveri, J. Biol. Chem. 178: 677-82, 1949.

35. Sumner, J. B., and Somers, G. F., Chemistry and Methods of Enzymes, Academic Press Inc., New York, N.Y., 1953.

36. Sutherland, E. W., Cori, C. F., Haynes, R., and Olsen, N. S., Purification of the hyperglycemic-glycogenolytic factor from insulin and from gastric mucosa, J. Biol. Chem. 180: 825-37, 1949.

37. Weil-Malherbe, H., The enzymatic phosphorylation of vitamin B, Biochem. $J$. 38: 1997-2007, 1939. 